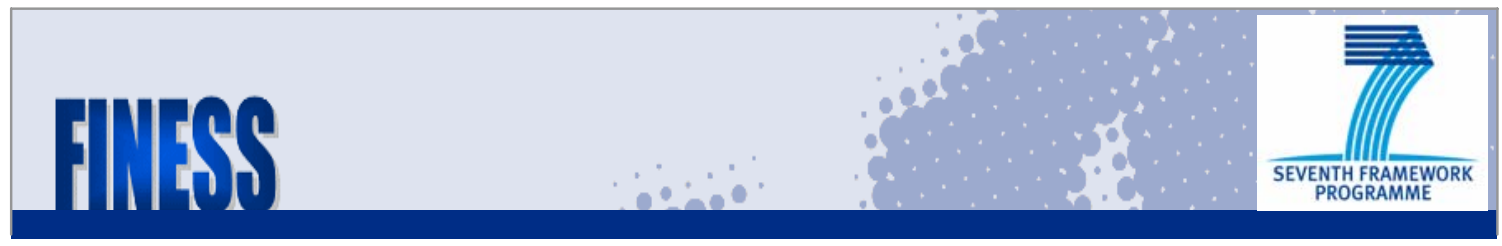

Project funded under the Socio-economic Sciences and Humanities

Working Paper D.2.2

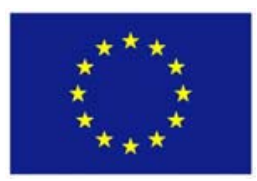

European Commission

\title{
Bank ownership, firm value and firm capital structure in Europe
}

\author{
Lieven Baert and Rudi Vander Vennet
}

February 2009 


\title{
Bank ownership, firm value and firm capital structure in Europe*
}

\author{
Lieven Baert* \\ Ghent University \\ Rudi Vander Vennet \\ Ghent University
}

\begin{abstract}
We investigate whether or not banks play a positive role in the ownership structure of European listed firms. We distinguish between banks and other institutional investors as shareholders and examine empirically the relationship beween financial institution ownership and the performance of the firms in which they hold equity. Our main finding is that after controlling for the capital structure decision of the firms and the ownership decision of financial institutions in a simultaneous equations model, we find that there is a negative relationship between financial institution ownership and the market value of firms, measured as the Tobin's Q. This is in contradiction with the monitoring hypothesis.
\end{abstract}

Key words: Financial institution ownership, Firm value, Capital structure JEL classification: G32, G20

\footnotetext{
* Financial support from the European Commission (7th Framework Programme, Grant Agreement No. 217266) is gratefully acknowledged..

* Corresponding author Email address: lieven. baert@ugent. be (Lieven Baert).
} 


\section{Introduction}

We investigate whether or not banks play a positive role in the ownership structure of European listed firms. How broad should the scope of banks in a modern economy be? One of the aspects of this question is related to bank involvement in the ownership and corporate governance of non-financial firms. Should the role of banks be restricted to financial intermediation or do banks also have a role to play as shareholders of non-financial corporations? We empirically examine the relationship between bank ownership and the performance of the firms in which they act as shareholders. In particular, we investigate whether or not banks and institutional investors add value by being shareholders in non-financial firms.

Research in the 1980s and 1990s concluded that German and Japanese firms benefited from the active involvement of their main bank in their corporate governance. This was part of the rationale for the deregulation of the banking systems in Europe. The Second Banking Directive of 1989 contains provisions allowing all banks to pursue strategies leading to a German-style universal bank. Banks can hold equity stakes in non-financial firms, be it subject to certain regulatory limits. Simultaneously, institutional investors such as mutual funds and pension funds have become more important as owners of corporate equity. Institutional investments in world equity markets have grown substantially in recent decades to such a degree that financial institutions have emerged as the largest investor class in many countries. According to the European Federation of Asset Managers, Europe represents the second largest asset management market in the world, next to the US. At the end of 2006,

the assets managed by the European asset management industry amounted 
to 13.5 trillion euro.

We distinguish between banks and other institutional investors as shareholders of a large sample of listed European firms. Banks, and the bank trusts they manage, are treated as a separate group as well as institutional investors, such as mutual funds, pension funds trusts, private equity firms, financial companies and insurance companies. Banks can hold both debt and equity in corporations. This combination may give banks additional power in the disciplining of corporate management. Institutional investors can only use the powers attached to their equity stakes to exert influence. Therefore, in the remainder of the paper, we use the distinction between banks and institutional investors. We focus on the effect of bank and institutional investor ownership on the external financing behavior and the long-term stock market valuation of the corporations.

The effect of ownership on firm value remains a key issue in corporate governance ever since Berle and Means' (1933) thesis that concentrated ownership is positive for firm value maximization. However, the association between concentrated ownership and firm value is not undisputed. Thomsen et al. (2006) find a negative relationship between blockholder ownership and firm value in continental Europe. Several studies have focused their attention on the impact of institutional ownership. Li et al. (2006) show that bank holdings are largely driven by a series of macroeconomic indicators identified in the law and finance literature. Chen et al. (2007) find that monitoring is more costly for banks than for independent institutions such as mutual fund managers and investment advisers. Ferreira and Matos (2008) use total stockholdings of financial institutions and find that banks have no discernable impact on firm value. The impact of institutional shareholdings on firm leverage has re- 
ceived considerably less attention. Much of the focus has been directed towards leverage and insider shareholdings. However, Mahrt-Smith (2005) shows that a judicious empirical analysis should include both the ownership structure and the capital structure features of firms, because omitting one or the other could lead to biased results. Empirically McConnell and Servaes (1995), Brailsford, Oliver and Pua (2002), Driffield et al. (2007) and Bhagat and Bolton (2008) take leverage explicitly into account.

Consequently, in our empirical setup we explore three relationships simultaneously. The first is the link between the ownership structure of firms and their performance, measured as the Tobin's Q. The second is the relationship between ownership and the firm-specific or institutional determinants. Since leverage may serve as a disciplining device, a third association is that between the observed leverage of a firm and its ownership structure, obviously with a special focus on banks, since they can hold both debt and equity. Hence, we analyse the following questions. What are the determinants of bank and institutional investor ownership in non-financial firms? What is the effect on the long-run corporate performance (measured as Tobin's q) of bank versus institutional investor ownership? What are the interactions between ownership, leverage and Q.

We use a panel of 2851 listed non-financial firms from EU15 for the period 1997-2006, leading to 13046 firm-year observations. For this sample of firms we combine balance sheet data (Amadeus) with market data (Datastream and Worldscope) and ownership data (Amadeus and Li et al. (2006)).

Our main finding is a negative and significant relationship between the degree of financial institution ownership and the value of firms in terms of 
Tobin's Q, implying that increased financial institution shareholding has a negative effect on shareholder value.

In the next section we review the literature and state the main hypotheses. We then present our data on listed non-financial firms, focusing on their ownership structure. In section 4 we examine the determinants of bank ownership and the impact of bank versus institutional investor ownership on firm value and leverage. We integrate these analyses in a simultaneous equation model. We conclude in Section 6 and discuss broader implications of our findings.

\section{Literature and hypotheses}

Why would banks and institutional investors acquire ownership stakes in non-financial corporations? And what is the effect of their involvement in corporate governance on the performance of the firms? We review several strands

of the literature related to these questions. First, the activities of financial institutions as shareholders have to be considered within the general governance and regulatory framework. Second, we review papers that investigate the role of financial institutions as shareholders. Third, we analyse whether or not these investors have an impact on the performance of the firms in which they hold equity stakes. Finally, we examine the role of leverage as one of the potential avenues for the disciplining of management.

Imperfections in capital, labor, and corporate control markets have made alternative sources of monitoring to inside monitoring by management necessary to mitigate agency conflicts within firms. Hence, from a corporate governance perspective, investigating the effects of concentrated shareholdings is 
important because large equity stakes should provide an incentive to monitor (Shleifer and Vishny (1986)). However, the free-rider problem, regulatory investment limits, as well as a preference for diversification and liquidity may make the acquisition of such equity stakes costly. Therefore, if financial institutions want to be large shareholders they will examine the trade-off between the gains and the costs associated with concentrated shareholdings. Li et al. (2006) compare concentrated equity positions of financial institutions across countries and find significant differences in the extent to which they elect to become large shareholders. They attribute these differences to regulatory corporate governance features such as shareholder protection, law enforcement and corporate disclosure requirements. When shareholder rights are stronger, when legal enforcement is more efficient, when there is greater access to voting right, or when financial disclosure is more extensive, financial institutions will tend to have large shareholdings. In other words, ownership concentration of financial institutions is to some extent complementary to shareholder protection. A result also found theoretically by Burkart and Panunzi (2006) who demonstrate that legal provisions can be a substitute for monitoring. Li et al. (2006) conclude that strong governance environments act to strengthen monitoring ability such that more institutions are encouraged to hold concentrated equity positions. Hence, when we investigate the determinants of bank and institutional investor shareholdings, we will include measures of legal quality and disclosure standards. Since we focus on firms headquartered in the European Union, regulatory differences are not expected to play a major role.

Hypothesis : Legal regime quality and disclosure quality should have a positive effect on bank ownership of firms.

The key issue is whether or not concentrated ownership has an observable 
effect on firm value. Holderness (2003) surveys the literature on the impact of outside (i.e., non-management) blockholders on firm value. He concludes that the evidence for the U.S. indicates that the relationship is sometimes negative, sometimes positive, but never very pronounced. McConnell and Servaes (1990) detect a positive relationship between Tobin's Q and the fraction of shares owned by institutions. The U.S. evidence does suggest that blockholders can enjoy significant private benefits of control. A number of studies document that block trades are typically priced at a premium to the exchange price, consistent with blockholders expecting benefits that are not available to other shareholders ( Barclay and Holderness (1989)). Thomsen et al. (2006) examine the relationship between blockholder ownership and the values of the largest companies in the European Union and the U.S. They find a negative association between blockholder ownership and firm value in Continental Europe, where ownership concentration is typically higher, the level of investor protection is lower, and influential blockholders may have objectives other than shareholder value. They find no significant association between blockholder ownership and prior or subsequent firm value in either the U.S. or the U.K which they interpret as evidence for conflicts of interest between blockholders and minority investors.

Hypothesis : Blockholder ownership has no significant effect on firm value.

The focus of this study is the investigation of the value added of banks as shareholders and compare this to the effect of other institutional investor ownership on firm value. It has been asserted that banks may play a special role in the corporate governance of firms because they can combine debt and equity. Banks have an incentive to monitor corporations to which they lend, especially when there is a main bank/firm relationship. Moreover, banks may 
obtain valuable information from their involvement in lending to non-financial firms, information that they can use in their monitoring role as shareholder. If there is complementarity between bank shareholding and bank lending, this should have a positive effect on firm value (see Barucci and Mattesini, 2008). On the other hand, the combination of debt and equity may raise potential conflicts of interest which may weaken the effectiveness of banks as monitors. Debt holders are inherently risk averse because they face downside risk on their loans. Shareholders are assumed to be less risk averse, especially when they hold a diversified portfolio of stocks. Also when we compare banks and other institutional investors in terms of monitoring potential, several effects may be at work. When institutional investors such as fund managers hold equity stakes in firms, they can monitor firm management through actions ranging from the sale of shares, the active use of voting rights or meetings with management. The more independent they are from the firms the stronger their influence can be. Banks can use their lending activity as an additional instrument to discipline management. However, it is also argued that banks may be locked in a lending relationship which may weaken their ability to influence firm management. Moreover, if a bank holding equity is primarily interested in ensuring the service of its outstanding debt, this would conflict with shareholders' interests (Brickley et al. (1988), Almazan et al. (1995)).

Hence, it remains an empirical matter to ascertain whether or not the involvement of banks in corporate governance affects the long term profitability of non-financial firms. The evidence on the relationship between bank shareholding and firm performance is mixed. For Japanese firms, Morck et al. (2000) report a nonlinear relationship between Tobin's q and bank shareholding. In Germany, Gorton and Schmid (2000) find that firm performance is positively 
affected by bank shareholding, but Chirinko and Elston (2006) report that bank control affects company profitability negatively, although significance is weak. Blass et al. (1998) report that banks are significant blockholders in Israel. They conclude, however, that the benefits that the powerful role of banks have for shareholders are outweighed by the costs, e.g., the lack of an external control market. Barucci and Mattesini (2008) examine the motivations behind banks' shareholding of non financial firms using a panel of large Italian companies in the period 1994-2000. They show that banks are shareholders of companies that are less profitable, have experienced slower growth, are more indebted, are endowed with collateral and have hard time to repay their debt out of current income. Banks are more likely to hold shares in companies they lend to. Overall the evidence suggests that there is complementarity between bank equity holding and lending.

Since banks may face limitations in their pursuit of shareholder value maximization, many have looked to institutional investors as alternative potential monitors. Moreover, since they collectively are the largest owners of equity, they have a clear incentive to maximize shareholder value. Pound (1991) and Black (1992b) discuss how institutional investors, as large shareholders, can become monitors and increase firm value. The argument that institutional monitors can increase firm value, however, implicitly assumes that they have objectives similar to other shareholders. As recognized by Black (1992a) and others, institutional monitors are also agents with their own source of agency conflicts. In certain types of institutional investors, such as public pension funds, this problem can be severe. However, Woidtke (2002) shows that firm value is positively related only to ownership by private pension funds. Gillan and Starks (2003) state that the rise of professional money managers as a large 
shareholder group in companies can increase the potential for monitoring of firm management. Institutions' involvement can range from threatening the sale of shares to the active use of corporate voting rights or meetings with management. Moreover, foreign institutional investors are often believed to play more of a role in prompting changes in corporate governance practices than domestic money managers.

Cornett et al. (2004) conclude that the presence of institutions without potential business relationships with the firm is associated with better firm operating performance. Chen et al. (2007) examine independent institutional investors that have maintained large stakes in a firm for at least one year (long-term) to specialize in monitoring activities, and show little short-term trading profit. Furthermore, monitoring institutions will benefit from their monitoring efforts, but at least some of this benefit will be shared with other stockholders. They conclude that the net benefits of monitoring increase with the size of the stake, the length of time invested, and the independence of the institution (absence of potential business ties) as monitoring is usually considered to cost less for independent than for so-called grey institutions. These institutions have a disadvantage in pressuring corporate managers for changes because it may harm their business relationships with the firm. Ferreira and Matos (2008) examine what drives institutional investors to firms and what role these investors play. Following Brickley et al. (1988), Almazan et al. (2005), and Chen et al. (2007), they divide institutions into two groups: independent institutions (mutual fund managers and investment advisers) and grey institutions (banks, bank trusts, insurance companies, and other institutions). Independent institutions tend to be "pressure-resistant," while grey institutions tend to be "pressure-sensitive" or loyal to corporate management. 
For example, they find that banks and insurance companies are more supportive of management actions than other types of institutional investors in antitakeover amendment proposals. They find that both types of institutions share a preference for large, widely held, and visible stocks consistent with findings in the U.S. market (Bennett et al. (2003)). The results also show that independent managers invest more in firms with liquid stock and firms in countries with strong legal environments, compared to grey managers (especially bank-controlled ones).

Hypothesis: Institutional investor ownership has a positive effect on firm value caused by stricter monitoring. Bank ownership has no significant effect on firm value.

The last question is how the capital structure of a firm influences the impact of shareholders on corporate performance. One of the avenues through which discipline can be imposed on corporate managers is the use of debt. The theoretical literature on ownership and capital structure predicts either higher or lower levels of financial leverage depending on the manager's risk aversion, the costs of monitoring and bankruptcy, the threat of takeovers, and the growth opportunities of the firm. Theories of ownership and capital structure emphasize the role of debt in reducing agency problems between managers and shareholders. Jensen and Meckling (1976), Fama (1980), and Grossman and Hart (1982) argue that managers prefer lower financial leverage because it reduces the risk of bankruptcy and protects their underdiversified human capital. Jensen (1986) argues that a larger level of debt pre-commits the manager to working harder to generate and pay off the firm's cash flows to outside investors and therefore reduces the overinvestment problem, particularly in firms with excess free cash flow. 
Mahrt-Smith (2005) models the ownership structure and capital structure jointly. The model shows that any empirical analysis should include both the ownership structure and the capital structure features of firms, because omitting one or the other could lead to loss of explanatory power or even biased results. Likewise, Driffield et al. (2007) argue that in attempting to determine the effect of ownership on both capital structure and firm value, we are faced with a simultaneity problem. McConnell and Servaes (1995), for example, argue that firm value and capital structure could be closely correlated, which is further reiterated in Berger and di Patti (2006). On the one hand, high leverage may reduce the agency costs of outside equity, and increase firm value by encouraging managers to act more in the interests of shareholders. On the other hand, there can be reverse causation from firm performance to capital structure. For example, more efficient firms may choose lower equity ratios than others, all else equal, because higher efficiency reduces the expected costs of bankruptcy and financial distress. More efficient firms may also choose higher equity capital ratios, all else equal, to protect the rents or franchise value associated with high efficiency from the possibility of liquidation (Berger and di Patti, 2003). The estimated coefficient of Q in the leverage equation would capture the net value of these two possible effects that work in opposite directions. If firm valuation affects the choice of capital structure and vice versa, then the failure to take this into account may result in a simultaneity bias, with important implications for the pattern of firm financing and valuation. According to Thomsen et al. (2006) firm value may have positive and negative feedback effects on blockholder ownership. Negative feedbackblockholder ownership drops following increases in firm value - may occur if blockholders are more inclined to sell shares in a firm when its share price is high (Zeckhouser and Pound (1990)). Positive feedback effects from firm value 
on blockholder ownership may occur if blockholders have a strong preference to remain in control (the control preference hypothesis), since a higher market price makes it possible to finance a given level of investment by issuing a smaller amount of stock to outside owners (La Porta et al. (2000)).

Hypothesis: when financial institutions are large shareholders, firms will hold more debt as a disciplining device for managers.

\section{Data}

\subsection{Ownership data}

The ownership data is obtained from AMADEUS provided by Bureau Van Dijk (BvD, Brussels). Several papers, such as Li et al. (2006), have used ownership data from BvD, primarily OSIRIS. The ownership data is identical in AMADEUS and OSIRIS as both products only differ in their scope. It is important to note that the starting point of this dataset is different from datasets such as Factset used in Ferreira and Matos (2008). BvD starts from the firm for which it collects balance sheet and ownership information. Factset collects shareholdings from financial institutions.

As we exploit ownership structure changes over time, we use AMADEUS DVDs for each year from 1999 to 2007. We retain shareholdings for the period 1997-2006 for listed non-financial firms in the EU15 for which detailed ownership data are available. We exclude financial firms from the sample because institutional investments in these firms may be motivated by different considerations. As BvD provides no historic ownership information, we obtain for 
each year a cross-section of the firms' ownership structure . BvD provides the date when a shareholder enters the ownership structure of a company. which enables us to reconstruct the shareholder structure. Before 1999, we take the conservative approach and use data from the most recent date.

Amadeus subdivides the shareholders in different types: Bank; Employees/Managers; Financial company; Foundation/Research Institute; Individual(s) or family(ies); Industrial company; Insurance company; Mutual \& Pension fund/Trust/Nominee; Other unnamed shareholders; Private Equity firms; Private individuals/private shareholder; Self-owned; State/Public authority; Unknown; Unnamed private shareholders. Since we focus on financial institutions and banks in particular, we control the accuracy of these entries. First, we control whether inconsistencies arise in shareholder type over the years. We use the most recent shareholder type since this proves to be the most accurate. Second, we control the names of the shareholders for keywords (in English or languages of the sample countries) that indicate whether a shareholder is a financial institution (e.g., "bank," "insurance company," etc.). Finally, we use a list of financial institutions provided by Li et al. (2006) to cross-check the financial institution shareholders in our sample. They use company information databases (Lexis/Nexis and Dun and Bradstreet), business news stories (through Factiva, Proquest, and the Google internet search engine), the shareholders' web sites and LionShares database constructed by Factset Research Systems, Inc., which collects shareholdings of more than 4,000 large investment managers domiciled around the world.

The final ownership dataset has 159389 observations which belong to 35349 different shareholders. Appendix B shows the distribution of the shareholder types. As percentage of total shareholdings AMADEUS provides alternatively 
the direct or total shareholding. When available we use total shareholding, otherwise direct shareholding.

Total financial institutional ownership (FI) is defined as the sum of the percentage holdings of all financial institutions in a firm's stock for each year. Following Gompers and Metrick (2001) and Ferreira and Matos (2008), we set financial institution ownership variables to zero if a stock is not held by any financial institution. Hence, these firms remain in the sample. Chen et al. (2007) and Ferreira and Matos (2008) classify institutions according to the potential for business ties with a corporation and distinguish independent (money managers) and grey institutions (banks and insurance companies). We focus on banks as shareholders and compare their influence with that of non-bank institutional investors, such as insurance companies, mutual funds, pension funds and private equity funds. As a result, bank ownership (BANK) is the percentage of shares held by banks and investment vehicles under their direct control. Institutional investors (INST INV) is the percentage of shares held by financial companies, insurance companies, mutual \& pension funds, trusts and private equity firms which are not part of a bank. Following Ferreira and Matos (2008) we also consider the geographic origin of the financial institution. FI/BANK/INST INV domestic is the sum of the percentage holdings of all financial institutions domiciled in the same country in which the stock is issued. FI/BANK/INST INV foreign is the sum of the percentage holdings of all institutions domiciled in a country different from the country in which the stock is issued. 


\subsection{Balance sheet data}

The sample of non-financial listed European firms is constructed from AMADEUS, a pan-European financial database that provides detailed balance sheet and income statement data for companies in Europe and standardized balance sheet information with the stated objective of achieving uniformity and enabling cross-border analysis. We select all consolidated listed firms of the EU15 for the period 1996-2006 . This sample of firms is merged with market data from Datastream, we use the ISIN code of the firm as identifier. To reduce the impact of outliers we winsorize the sample at the 1st and 99th percentile. We delete all observations for which one of the variables is missing. Appen-

dix A presents an overview of the firm-specific variables used in our empirical analysis. The construction of the variables is standard in the literature (see, e.g., Flannery and Rangan (2006) for the determinants of corporate leverage and Ferreira and Matos (2008) for the determinants of financial institution ownership).

\subsection{Country variables.}

In the regressions we include country-specific variables to account for any differences across countries. However, since we focus on the 15 countries of the 'old' European Union, we do not expect that country differences should explain a lot of the cross-sectional variation across firms. The EU has implemented a broad range of legal provisions aimed at harmonising the institutional and business conditions across the EU. We include the quality of a country's legal environment (LEGAL) and an index on strength of auditing 
and reporting standards (AUDIT) from the Global competitiveness report to assess the transparancy of business life in the respective countries.

We include two indicators of financial market development obtained from the Financial Development and Structure database of the World Bank. We use private bond market capitalization to GDP, calculated as the ratio of private domestic debt securities as a share of GDP, as a proxy for the development of the bond market, and a measure of stock market development, i.e. the value of listed shares to GDP to proxy for the development of stock markets.

The final dataset contains 2851 listed non-financial firms from EU15 for the period 1997-2006, leading to 13046 firm-year observations. See Table 1 for the summary statistics of the variables.

\section{Empirical strategy}

We argue that the effect of financial institution ownership on corporate performance should be analysed in a broad but coherent framework. Hence, we need to explore the interactions between ownership, firm capital structure and performance. The empirical analysis proceeds in steps. First, we investigate the determinants of financial institution ownership. In the next step we examine the relationship between corporate performance, measured as Tobin's Q, and financial institution shareholdings. This analysis is gradually augmented, starting with a single-equation specification for $\mathrm{Q}$ and ending with a threeequation model in which all interactions are estimated simultaneously. All variable definitions can be found in Appendix A. 


\subsection{Determinants}

We start with the determinants of corporate ownership by the different types of financial institutions:

$$
\begin{aligned}
& O w n_{i j t}=\alpha_{0}+\alpha_{1} L_{n T A_{i j t}}+\alpha_{2} M B_{i j t}+\alpha_{3} T U R N O V E R_{i j t}+\alpha_{4} D Y_{i j t}+\alpha_{5} R O E_{i j t} \\
& +\alpha_{6} S D_{i j t}+\alpha_{7} B D R_{i j t}+\alpha_{8} C A S H_{i j t}+\alpha_{9} C L O S E_{i j t}+\alpha_{10} A U D I T_{j t} \\
& +\alpha_{11} L E G A L_{j t}+\alpha_{12} \text { BOND }_{j t}+\alpha_{13} S T O C K_{j t}+\text { yeardummies }+\epsilon_{i j t}
\end{aligned}
$$

We proceed by estimating the effect of ownership by banks and institutional investors on firm value. The first model treats all regressors as exogenous.

$$
\begin{gathered}
Q_{i j t}=\beta_{0}+\beta_{1} O w n_{i j t}+\beta_{2} L n T A_{i j t}+\beta_{3} B D R_{i j t}+\beta_{4} C A S H_{i j t}+\beta_{5} Q_{-} \text {med }_{i j t} \\
+\beta_{6} A U D I T_{i j t}+\beta_{7} L E G A L_{i j t}+\beta_{8} B O N D_{j t}+\beta_{9} S T O C K_{j t}+\text { year dummies }+\eta_{i j t}
\end{gathered}
$$

The second model is a system of equations linking the determinants of firm value and ownership (similar to Ferreira and Matos (2008):

$$
\begin{aligned}
& Q_{i j t}=\delta_{q, 0}+\delta_{q, 1} O w n_{i j t}+\delta_{q, 2} L n T A_{i j t}+\delta_{q, 3} B D R_{i j t}+\delta_{q, 4} C A S H_{i j t}+\delta_{q, 5} Q \text { med }_{i j t} \\
& +\delta_{q, 6} A U D I T_{i j t}+\delta_{q, 7} L E G A L_{i j t}+\delta_{q, 8} B O N D_{j t}+\delta_{q, 9} S T O C K_{j t}+\text { year dummies }+\nu_{q, i j t} \\
& O w n_{i j t}=\delta_{o w n, 0}+\delta_{o w n, 1} Q_{i j t}+\delta_{o w n, 2} L n T A_{i j t}+\delta_{o w n, 3} M B_{i j t}+\delta_{o w n, 4} T U R N O V E R_{i j t}+\delta_{o w n, 5} D Y_{i j t} \\
& +\delta_{o w n, 6} R O E_{i j t}+\delta_{o w n, 7} S D_{i j t}+\delta_{o w n, 8} B D R_{i j t}+\delta_{o w n, 9} C A S H_{i j t}+\delta_{o w n, 10} C L O S E_{i j t} \\
& +\delta_{o w n, 11} A U D I T_{j t}+\delta_{o w n, 12} L E G A L_{j t}+\delta_{o w n, 13} B O N D_{j t}+\delta_{o w n, 14} S T O C K_{j t}+\text { year dummies }+\epsilon_{i j t}
\end{aligned}
$$

The third model is a system of three equations capturing the determinants of firm value, ownership and leverage. Identification in the leverage equation is obtained by using fixed assets of the company, depreciation, profitability and 
the median industry capital structure (see Baert and Vander Vennet (2008) and Flannery and Rangan (2006)):

$$
\begin{gathered}
Q_{i j t}=\gamma_{q, 0}+\gamma_{q, 1} O w n_{i j t}+\gamma_{q, 2} L n T A_{i j t}+\gamma_{q, 3} B D R_{i j t}+\gamma_{q, 4} C A S H_{i j t}+\gamma_{q, 5} Q \text { med }_{i j t} \\
+\gamma_{q, 6} A U D I T_{i j t}+\gamma_{q, 7} L E G A L_{i j t}+\gamma_{q, 8} B O N D_{j t}+\gamma_{q, 9} S T O C K_{j t}+\text { year dummies }+\nu_{q, i j t} \\
O w n_{i j t}=\gamma_{o w n, 0}+\gamma_{o w n, 1} Q_{i j t}+\gamma_{o w n, 2} L n T A_{i j t}+\gamma_{o w n, 3} M B_{i j t}+\gamma_{o w n, 4} T U R N O V E R_{i j t}+\gamma_{o w n, 5} D Y_{i j t} \\
+\gamma_{o w n, 6} R O E_{i j t}+\gamma_{o w n, 7} S D_{i j t}+\gamma_{o w n, 8} B D R_{i j t}+\gamma_{o w n, 9} C A S H_{i j t}+\gamma_{o w n, 10} C L O S E_{i j t} \\
+\gamma_{o w n, 11} A U D I T_{j t}+\gamma_{o w n, 12} L E G A L_{j t}+\gamma_{o w n, 13} B O N D_{j t}+\gamma_{o w n, 14} S T O C K_{j t}+\text { year dummies } \\
B D R i j t=\gamma_{l e v, 0}+\gamma_{l e v, 1} O w n_{i j t}+\gamma_{l e v, 2} Q_{i j t}+\gamma_{l e v, 3} C A S H_{i j t}+\gamma_{l e v, 4} F A_{-} T A_{i j t}+\gamma_{l e v, 5} D E P T \_T A_{i j t} \\
+\gamma_{l e v, 6} E B I T \_T A_{i j t}+\gamma_{l e v, 7} B D R \_m e R_{i j t}+\gamma_{l e v, 8} A U D I T_{j t}+\gamma_{l e v, 9} L E G A L_{j t}+\gamma_{l e v, 10} B O N D_{j t} \\
+\gamma_{l e v, 11} S T O C K_{j t}+y e a r d u m m i e s+\nu_{l e v, i j t} \quad(4)
\end{gathered}
$$

Consequently, in our empirical setup we explore three relationships simultaneously. The first is the link between the ownership structure of firms and their performance, measured as the Tobin's Q. $Q=f$ (bank ownership, $B D R, X)$. The second is the relationship between bank ownership and firm specific determinants. bank ownership $=f(B D R, Q, Y)$ The third association is that between the observed leverage of a firm and its ownership structure, with a special focus on banks, since they can hold both debt and equity, $B D R$ $=f($ bank ownership, $Q, Z) . X, Y$ and $Z$ contain the respective control variables. 


\section{Results}

\subsection{What determines financial institution ownership?}

We start with the determinants of financial institutions ownership in nonfinancial firms. The estimated model is similar to the one in Ferreira and Matos (2008). This should allow comparison of the findings, although the country coverage is broader in their sample while we focus on the European Union. We examine the ownership preferences of banks versus non-bank institutional investors as well as the differences between domestic and foreign institutions.

\subsubsection{Banks versus institutional investors}

We start by examining which firm- and country-level characteristics affect financial institution ownership, subdivided in banks and non-bank institutional investors. Table 2 presents the estimates of the ownership panel regressions, the first two columns contain the results for all financial institutions, the next two for banks and the last two for institutional investors. For each type of owner, we estimate two specifications: OLS with firm- and country-level variables and OLS with firm-level variables and country fixed effects. We use panel corrected standard errors allowing for heterogeneity at the firm level (Rogers standard errors) together with year dummies (dummy for 2006 is excluded) to control for residual correlation across years and residual correlation across firms in a given year. When country dummies are included we exclude the dummy for the U.K. The results show that financial institutions share two common preferences in their choice to become shareholders: firm size and the closeness of the ownership structure. The main common driver of financial 
institution ownership is the size of the firm, the estimated coefficient is always positive and significant. The finding that financial institutions prefer equity holdings in large European firms is consistent with similar findings for different samples, e.g., Falkenstein (1996) and Gompers and Metrick (2001) for the U.S. market, Dahlquist and Robertsson (2001) for the Swedish market and Ferreira and Matos (2008) for a broad international sample. The rationale is that financial institutions have concerns about liquidity and transaction costs. Investing in the equity of large corporations alleviates these concerns. Second, all financial institutions avoid holding equity in closely held firms, the coefficient on CLOSE is always negative and significant. Investors may shy away from firms that are closely held, fearing the power of insiders to expropriate firm resources at the expense of minority shareholders. La Porta et al. (1999), Leuz et al. (2006) and Ammer et al. (2006) also find that outside investors avoid ownership in closely held companies.

Firm ownership of all financial institutions is positively affected by the dividend yield of the corporations. However, this effect is largely driven by the institutional investors. This finding is expected since fund managers have a fiduciary obligation to their investors and hence prefer stocks paying regular dividends. As in Ferreira an Matos (2008), we find that financial institutions do not avoid stock market volatility, measured here as the standard deviation of stock returns. While this is contrary to the predictions of the "prudent man" rules (Del Guercio (1996)), which Gompers and Metrick (2001) also find for money managers in the U.S., it is consistent with the interpretation that institutional investors seek dividend yield in the first place and are able to alleviate idiosyncratic firm risk by diversifying their equity holdings. Banks, on the other hand, avoid high idiosyncratic volatility stocks, because they hold 
less diversified equity portfolios. Finally, banks prefer stocks in firms with a relatively high level of leverage (BDR), the coefficient is positive and significant. This may be an indication of the complementarity of debt and equity for banks as owners. The country-level variables reveal that all financial institutions prefer stocks from companies located in countries with sound legal regimes and especially the non-bank institutional investors prefer countries with large bond and stock markets. This suggests that institutional investors have a preference for liquid markets. In that respect, the negative sign of the stock market turnover ratio is somewhat counterintuitive.

\subsubsection{Domestic versus foreign financial institutions as firm owners}

We also examine whether the country of origin of the different types of financial institutions affects the results. Table 3 presents estimates of the determinants of financial institution ownership by institution type and whether or not they are from the same country as the firms in which they hold equity (domestic/foreign). All institutions have a strong preference for large firms except domestic non-banks, which may reflect some degree of home bias in the stockholdings of domestic institutional investors. Apart from the firm size variable, no consistent patterns emerge. Closely held firms are not favored by foreign banks and domestic non-banks. Dividend yield only affects the ownership of domestic financial institutions while it remains insignificant for foreign institutions, perhaps because of tax concerns (Dahlquist and Robertsson (2001); Ammer et al. (2005)). On the other hand, foreign financial institutions of both types seem to prefer investments in liquid stocks (TURNOVER) and less risk stocks (standard deviation of returns $(\mathrm{SD})$ ). The positive association between

leverage and bank ownership is only found for domestic banks. The quality of 
a country's legal environment (LEGAL) is positively related to the presence of all financial institutions, consistent with the law and finance literature (La Porta et al. (1998)).

\subsection{Effect of financial institution ownership on corporate performance}

\subsubsection{Single equation}

To investigate the relation between institutional ownership and firm value, we adopt Tobin's Q as a measure of firm value, calculated as the book value of total assets plus the market value of equity minus the book value of equity divided by total assets (Gompers et al. (2003); Doidge et al. (2004)). Since Tobin's Q contains the stock market value of the firms' equity, it is a forwardlooking measure of firm performance. It captures the long-term profit potential

of each firm as assessed by the stock market. In this respect, it is a more complete indicator of company performance than accounting profits, which are inherently backward looking. Using a market value indicator, i.e. the value of the discounted future cash flows generated by the investment in a firm's stock, also alleviates the endogeneity issue.

Following Ferreira and Matos (2008) we estimate regressions of a firm's Tobin's $Q$ on variables associated with firm value such as size (LnTA), leverage (BDR), cash holdings (CASH), and median Tobin's Q for the firm's industry. We also include country-level variables that are usually considered in the literature. Most important, we include the financial institution ownership variables that are our focus, namely total financial institutions, banks and non-bank institutional investors. The findings are reported in table 4, the first regression 
includes year dummies and country-level variables, the second regression includes both year and country dummies. The main result of table 4 is that, irrespective of the type of financial institution, there is no significant relationship of financial institution ownership with firm value. All coefficients on financial institutions and the subgroups banks and institutional investors are insignificant. This finding is in line with the result that Ferreira and Matos (2008) report for what they label grey institutions, which include banks. However, they report a positive effect of independent financial investor ownership, which include mutual and pension funds, on firm value. One potential explanation is that our sample coverage differs from theirs, we focus on European firms, their country coverage is broader. Table 5 shows that our results remain unaltered when we use $\log (\mathrm{Q})$ or $-1 / \mathrm{Q}$ instead of $\mathrm{Q}$. This is also the case when we replace Tobin's Q with return on assets (ROA) as an accounting measure of corporate profitability (Table 6).

The behavior of the control variables is generally consistent with expectations and with the findings reported in Ferreira and Matos (2008). Large and cash-rich firms have higher valuations. The individual firm's Tobin's Q is positively affected by the median $\mathrm{Q}$ in its industry. And higher leverage (BDR) has a negative effect on Tobin's Q. Hence, after accounting for the effect of a set of standard control variables, we find that there is no effect from financial institution ownership both on the long-run performance potential and on a short-term profit measure of the European listed firms in our sample. 


\subsubsection{Simultaneous equations}

A potential explanation for these non-results is the possible endogeneity of financial institution shareholdings and the capital structure of firms. As we explain in the hypothesis section, financial institutions ownership may be driven by a specific set of determinants (see Table 2). Similarly, the capital structure decisions of firms may be determined by a specific set of firm-specific variables. Hence, our preferred specification is a system of simultaneous equations which captures the drivers of the leverage and the ownership decision and which employs these interactions to determine the ultimate effect on the long-term profit potential of listed firms. We proceed in two steps. The first setup considers two equations using three-stage least squares estimation, one for the ownership decision of financial institutions and the second for the determinants of Tobin's Q. This is similar to the approach used in Ferreira and Matos (2008).

The results are in table 7 . The effect of financial institution ownership on Tobin's Q is negative and significant and this holds for both banks and nonbank institutional investors. This evidence is inconsistent with any form of the monitoring hypothesis. It is noteworthy that the negative association with long-term corporate performance holds both for banks and non-bank institutional investors. Apparently, neither of these shareholder types can exert sufficient influence to have an impact on firm performance.

The coefficients in the ownership equation indicate that financial institution ownership is positively affected by firm size, indicating that these owners have a preference for large companies, and by dividend yield, indicating a preference

for firms paying the largest dividends. Moreover, the variable capturing the 
riskiness of the stock, SD or the standard deviation of stock market returns, is negative and significant. Combined these findings suggest that both banks and institutional investors act as 'normal' stock market investors, seeking cash returns and avoiding risk. Institutional investors display a higher coefficient on dividend yield, in accordance with their objective as fiduciary investors. The negative coefficient on CLOSE is also in line with previous findings (see Ferreira and Matos (2008)), as well as the country-specific indicators of legal quality and bond and stock market development. When we consider the coefficients of the Tobin's Q equation, the results are broadly similar to the ones in table 4. Median industry Q, cash holdings and the size of the firm display a positive association with its market value. The book leverage variable has a negative impact on Q, as in Ferreira and Matos (2008). Given the expected behavior of the control variables, the finding that financial institutions add no (market) value as shareholders can only be interpreted as a lack of monitoring influence on corporate management.

The results remain qualitatively unaltered when we replace $\mathrm{Q}$ with $\log (\mathrm{Q})$ as the dependent variable (Table 8). This is also the case when we treat ROA as the dependent variable (Table 9). Hence, the negative contribution to firm performance of banks and institutional investors as shareholders even holds for a short-term profit measure. This reinforces the interpretation that not only institutional investors but also banks lack the capacity to influence corporate management in terms of profit generation.

A two-equation system enriches the analysis. But we argue that a more complete setup should also include an explicit modeling of the capital structure decision. Banks can hold both debt and equity and can potentially use both financing means to influence corporate management. Institutional investors 
only hold equity and can only exert influence as shareholders. Therefore, in the final empirical step, we augment our system of simultaneous equations with a leverage equation. In Table 10 we report the results of three-stage least squares (3SLS) regressions of a system of simultaneous equations for Tobin's Q, financial institution ownership and leverage. The interpretation is as follows: after controlling for the firm's leverage decision, the ownership decision by financial institutions and a series of commonly used firm- and countryspecific determinants of Tobin's Q, we find that financial institution ownership is negatively associated with the long-term profit potential of European listed firms. This negative market value effect holds both for banks and institutional investors. The results for the three-equation system corroborate those of the two-equation setup. Apparently, financial institutions treat their shareholdings in non-financial firms as pure investments, rather than as an instrument to influence corporate management. Again, the results are robust for alternative indicators of firm performance as the dependent variable, i.e. $\log (\mathrm{Q})$ (Table 11) and also ROA (Table 12). In table 13 we perform an additional robustness check to alleviate the potential endogeneity problem by including the one-period lagged values of the explanatory variables. All results remain unaltered. In fact, the finding that financial institutions prefer shareholdings in large, cash-rich, high dividend yield and widely held firms is even strengthened. Furthermore, when we split the sample into quartiles according to the size of the firms or restrict the sample to companies with positive profitability or rerun the regression for Germany and the U.K. sereperately as these countries represent the extremes in ownership culture in Europe or take only firms with positive financial institution ownership the results remain unaltered. 


\section{Conclusions}

We investigate the relationship between financial institution ownership, corporate leverage and the market value of a of 2851 listed non-financial firms from EU15 for the period 1997-2006. More specifically, we focus on the value added of banks versus institutional investors in their role as shareholders on non-financial firms. Our main results can be summarized as follows.

First, we report that financial institutions, both bank and non-banks, typically hold equity stakes in large, cash rich and widely held firms which are moreover characterized by high dividend yield and a lower than average investment risk, measured as the volatility of the weekly stock market returns. The preference for dividends and low-risk stocks is most pronounced for institutional investors. We interpret these findings as evidence that financial institutions behave like typical investors, seeking return rather than influence.

Second, after controlling for the captial structure decision of the firms and the ownership decision of financial institutions in a simultaneous equations model, we find that there is a negative relationship between financial institution ownership and the market value of firms, measured as the Tobin's Q. This negative value effect holds for banks as well as institutional investors. This is in sharp contradiction with the monitoring hypothesis. We find no evidence that banks, which can use both debt and equity as potential monitoring insturments, as well as institutional shareholders are effective monitors of corporate management. This questions their rol as shareholders.

Third, although the presence of financial institutions in the ownership structure of firms is associated with higher levels of leverage, this feature does not 
function as an effective disciplining device for managers. Instead we find a negative association between leverage and the market value of firms.

Over the sample period, banks have reduced their equity holdings in nonfinancial firms. Given our results, this seems to be socially optimal. Tax measures to allow banks to dispose of their equity stakes, such as the one enacted in Germany point in the direction that banks themselves are aware of the fact that their influence on corporate management is limited. Now that the financial crisis forces banks and regulators to review the scope of banking franchises it might be advisable to restrict banks to hold equity of non-financial firms. Banks should focus on intermediation and not combine lending and equity stakes, because this creates conflicts of interest.

Institutional investors have become more important as shareholders. Yet our results indicate that their value added in terms of creating shareholder value is limited. This may have different reasons. One plausible explanation could be that most institutional investors, such as mutual funds and pension funds, have fiduciary duties to their own investors and typically track large stocks in widely used stock market indices. This would imply that they merely act as investors and do not seek to monitor or influence corporate managers. In order to provoke a more active stance as shareholder it would be advisable to encourage this class of owners to use their voting rights more actively.

\section{References}

[1] Almazan, A., J. Hartzell and L. Starks (2005). Active institutional shareholders and costs of monitoring: Evidence from executive compensation. Financial Management 34: 5-34. 
[2] Ammer, J., S. Holland, D. Smith and F. Warnock (2005). Look at me now: what attracts U.S. shareholders? Working paper. Federal Reserve Board of Governors.

[3] Baert, L. and R. Vander Vennet (2008). Bank market structure and firm capital structure in Europe. Working paper. FINESS.

[4] Barclay, M. and C. Holderness (1989). Private benefits from control of public corporations. Journal of Financial Economics 25(2): 371-395.

[5] Barucci, E. and Mattesini F. (2008). Bank shareholding and lending: Complementarity or substitution? Some evidence from a panel of large Italian firms. Journal of Banking and Finance 32: 2237-2247.

[6] Bennett, J., R. Sias and L. Starks (2003). Greener pastures and the impact of dynamic institutional preferences. Review of Financial Studies 16(4): 1203-1238.

[7] Berger, A. and E. di Patti (2006). Capital structure and firm performance: A new approach to testing agency theory and an application to the banking industry. Journal of Banking and Finance 30: 1065-1102.

[8] Berle, A. and G Means (1932). The Modern Corporation and Private Property, New York, NY, Macmillan Publishing Company.

[9] Bhagat, S. and B. Bolton (2008). Corporate governance and firm performance. Journal of Corporate Finance 14(3): 257-273.

[10] Black, B. (1992a). Agents watching agents: The promise of institutional investor voice. UCLA Law Review 39: 811-892.

[11] Black, B. (1992b). The value of institutional investor monitoring: The empirical evidence. UCLA Law Review 39: 895-939.

[12] Brailsford, T., B. Oliver, et al. (2002). On the Relation between Ownership Structure and Capital Structure. Accounting and Finance 42: 1-26. 
[13] Brickley, J., R. Lease and C. Smith (1988). Ownership structure and voting on antitakeover amendments. Journal of Financial Economics 20: 267-291.

[14] Burkart, M. and F. Panunzi (2006). Agency Conflicts, Ownership Concentration, and Legal Shareholder Protection. Journal of Financial Intermediation 15: 1-31.

[15] Chen, X., J. Harford and K. Li (2007). Monitoring: Which Institutions Matter. Journal of Financial Economics 86: 279-305.

[16] Chirinko, R. and J. Elston (2006). Finance, control and profitability: the influence of German banks. Journal of Economic Behavior and Organisation 59(1): 69-88.

[17] Cornett, M., A. Marcus, A. Saunders, and H. Tehranian (2007). The impact of institutional ownership on corporate operating performance. Journal of Banking and Finance 3: 1771-1794.

[18] Dahlquist, M., and G. Robertsson (2001). Direct foreign ownership, institutional investors, and firm characteristics. Journal of Financial Economics 59: 413-440.

[19] Del Guercio, D. (1996). The distorting effect of the prudent man law on institutional equity investments. Journal of Financial Economics 40: 31-62.

[20] Demsetz, H., and K. Lehn (1985), The Structure of Corporate Ownership: Causes and Consequences. Journal of Political Economy 93: 1155-1177.

[21] Denis, D. and J. McConnel (2003). International Corporate Governance. Journal of Financial and Quantitative Analysis 38(1): 1- 36.

[22] Doidge, C., G. Karolyi and R. Stulz (2004). Why are foreign firms listed in the U.S. worth more? Journal of Financial Economics 71: 205-238.

[23] Driffield, N., V. Mahambare and S. Pal (2007). How does ownership structure affect capital structure and firm value? Economics of Transition 15(3): 535-573. 
[24] Falkenstein, E. (1996). Preferences for stock characteristics as revealed by mutual fund portfolio holdings. Journal of Finance 51: 111-135.

[25] Fama, E. (1980). Agency problems and the theory of the firm. Journal of Political Economy 88(2): 288-307.

[26] Fama, E. and J. Jensen (1983). Seperation of Ownership and Control. Journal of Law and Economics 26(2): 301-325.

[27] Ferreira, M. and P. Matos (2008). The Colors of Investors' Money: the Role of Institutional Investors around the World. Journal of Financial Economics 88: $499-533$.

[28] Flannery, M. and K. Rangan (2006). Partial adjustment toward target capital structures. Journal of Financial Economics 79: 469-506.

[29] Gillan, S. and L. Starks (2003). Corporate Governance, Corporate Ownership, and the Role of Institutional Investors: A Global Perspective. Journal of Applied Finance 13: 4-22.

[30] Gompers, P., J. Ishii and A. Metrick (2003). Corporate goverance and equity prices. Quarterly Journal of Economics 118: 107-155.

[31] Gompers, P. and A. Metrick (2001). Institutional investors and equity prices. Quarterly Journal of Economics 116: 229-259.

[32] Gorton, G., and F. Schmid (2000). Universal Banking and the Performance of German Firms. Journal of Financial Economics 58: 28-80.

[33] Grossman, S. and O. Hart (1982). Corporate Financial Structure and Managerial Incentives. In: The Economics of Information and Uncertainty. Ed. by J. J. McCall. Chicago: The University of Chicago Press: 123-155.

[34] Holderness, C. (2003). A Survey of Blockholders and Corporate Control. FRBNY Economic Policy Review: 51-64. 
[35] Jensen, M. (1986). Agency costs of Free Cash Flow, Corporate Finance, and Takeovers. American Economic Review 76: 323-329.

[36] Jensen, M. and W. Meckling (1976). Theory of the Firm: Managerial Behavior, Agency Costs and Ownership Structure. Journal of Financial Economics 3: 305360.

[37] La Porta, R., F. Lopez-de-Silanes, A. Shleifer and R. Vishny (1998) Law and Finance. The Journal of Political Economy 106(6): 1113-1155.

[38] La Porta, R., F. Lopez-de-Silanes, et al. (1999). Corporate Ownership Around the World. Journal of Finance 54(2): 471-517.

[39] La Porta, R., F. Lopez-de-Silanes, et al. (2000). Investor Protection and Corporate Governance. Journal of Financial Economics 58: 3-27.

[40] Leuz, C., K. Lins and F. Warnock (2008). Do foreigners invest less in poorly governed firms? Working paper. ECGI.

[41] Li, D., F. Moshirian, P. Kien Pham and J. Zein (2006). When Financial Institutions are Large Shareholders: The Role of Marcro Corporate Governance Environments. Journal of Finance 61(6): 2975-3007

[42] Mahrt-Smith, J. (2005). The Interaction of Capital Structure and Ownership Structure. Journal of Business 75(3): 787-815.

[43] McConnell, J. and H. Servaes (1990). Additional Evidence on Equity Ownership and Corporate Value. Journal of Financial Economics 27(2): 595-612.

[44] McConnell, J. and H. Servaes (1995). Equity ownership and the two faces of debt. Journal of Financial Economics 39: 131-157.

[45] Morck, R., M. Nakamura and A. Shivdasani (2000). Banks, Ownership Structure, and Firm Value in Japan. Journal of Business 73: 539-567. 
[46] Petersen, M. (2009). Estimating standard errors in finance panel data sets: comparing approaches. Review of Financial Studies 22: 435-480.

[47] Pound J. (1991). Proxy voting and the SEC - Investor protection versus marketefficiency. Journal of Financial Economics 29(2): 241-285.

[48] Shleifer, A. and R. Vishny (1986). Large Shareholders and Corporate Control. Journal of Political Economy 94(3): 461-488.

[49] Thomsen, S., T. Pedersen and H. Kvist (2006). Blockholder Ownership: Effects of Firm Value in Market and Control Based Governance Systems. Journal of Corporate Finance 12: 246-269.

[50] Tirole, J. (2005). The theory of Corporate Finance. Princeton and Oxford, Princeton University Press.

[51] Woidtke, T. (2002). Agents watching agents?: evidence from pension fund ownership and firm value. Journal of Financial Economics 63: 99-131.

[52] Zeckhouser, R. and J. Pound (1990). Are large shareholders effective monitors? An investigation of share ownership and corporate performance.In: HUBBARD, G. R. (ed.). Asymmetric information, corporate finance and investment. University of Chicago Press. 
Table 1

Summary stats

This table reports mean, standard deviation, minimum, maximum, and number of observations (Obs) of variables. All variables are defined in Appendix A. The sample period is from 1997 to 2006.

\begin{tabular}{lrrrrr}
\hline Variable & Obs & \multicolumn{2}{c}{ Mean } & Std. Dev. Min & Max \\
\hline FI & 13046 & 0.288 & 0.278 & 0 & 1 \\
BANK & 13046 & 0.055 & 0.104 & 0 & 1 \\
INST INV & 13046 & 0.235 & 0.247 & 0 & 1 \\
FI domestic & 13046 & 0.225 & 0.251 & 0 & 1 \\
BANK domestic & 13046 & 0.041 & 0.092 & 0 & 1 \\
INST INV domestic & 13046 & 0.184 & 0.222 & 0 & 1 \\
FI foreign & 13046 & 0.065 & 0.121 & 0 & 1 \\
BANK foreign & 13046 & 0.014 & 0.045 & 0 & 0.996 \\
INST INV foreign & 13046 & 0.052 & 0.104 & 0 & 1 \\
CLOSE & 13046 & 0.408 & 0.261 & 0.0003 & 0.980 \\
ROA & 12996 & 3.704 & 12.447 & -77.23 & 31.68 \\
ROE & 13046 & 0.034 & 0.441 & -3.249 & 0.856 \\
DY & 13046 & 0.028 & 0.027 & 0 & 0.1493 \\
SD & 13046 & 0.535 & 1.530 & 0 & 8.689 \\
AUDIT & 13046 & 5.888 & 0.378 & 4.4 & 6.2 \\
LEGAL & 13046 & 31.211 & 13.225 & 0 & 42.85 \\
TURNOVER & 13046 & 0.545 & 0.595 & 0 & 3.538 \\
CASH & 13046 & 0.105 & 0.126 & 0 & 0.820 \\
BDR & 13046 & 0.206 & 0.170 & 0 & 0.798 \\
BDR_med & 13046 & 0.181 & 0.077 & 0.046 & 0.378 \\
LnTA & 13046 & 19.283 & 1.931 & 14.037 & 24.126 \\
EBIT_TA & 13046 & 0.050 & 0.139 & -0.949 & 0.339 \\
MB & 13046 & 1.251 & 1.133 & 0.155 & 8.5619 \\
DEP_TA & 13046 & 0.047 & 0.039 & 0 & 0.283 \\
FA_TA & 13046 & 0.302 & 0.245 & 0 & 0.997 \\
Q & 13046 & 1.933 & 1.178 & 0.366 & 9.669 \\
Q_med & 13046 & 1.647 & 0.306 & 1.219 & 2.860 \\
& & & & & \\
\hline & & & & &
\end{tabular}


Table 2

\section{Determinants of financial institutions}

This table reports estimates of coefficients of the annual time-series cross-sectional firm-level regression of ownership for all financial institutions (FI), banks (BANK) and institutional investors (INST INV). All regressions inlcude the firm-level regressors log of total assets (LnTA), log book-to-market (BM), turnover (TURNOVER), dividend yield (DY), return on equity (ROE), standard deviation of weekly returns (SD), leverage (BDR), cash holdings (CASH) and closely held shares (CLOSE). All regressions include the country-level regressors market capitalization of the private bond market to GDP (BOND MARKET), and market capitalization of the stock market to GDP (STOCK MARKET). Regression 1, 3 and 5 also include the country-level regressors strength of auditing and reporting (AUDIT) and legal regime index (LEGAL) whereas regression 2, 4 and 6 include country dummies. Refer to Appendix A for variable definitions. The sample period is from 1997 to 2006 . The robust t-statistics in parentheses are adjusted for clustering at the firm-level. Coefficients significant at the $5 \%$ level are in boldface.

\begin{tabular}{|c|c|c|c|c|c|c|}
\hline & -1 & -2 & -3 & -4 & -5 & -6 \\
\hline & $\bar{F}$ & & $\overline{\mathrm{BAl}}$ & & INST & \\
\hline LnTA & 0.015 & 0.013 & 0.005 & 0.003 & 0.009 & 0.01 \\
\hline & {$[5.69]^{\star *}$} & {$[4.76]^{\star \star}$} & {$[5.22]^{* *}$} & {$[3.60]^{\star \star}$} & {$[4.14]^{\star \star}$} & {$[3.97]^{\star \star}$} \\
\hline MB & -0.001 & 0 & -0.001 & -0.001 & -0.001 & 0 \\
\hline & {$[0.30]$} & [0.15] & {$[0.46]$} & [1.14] & {$[0.28]$} & {$[0.16]$} \\
\hline TURNOVER & -0.013 & -0.009 & 0.005 & 0.005 & -0.019 & -0.014 \\
\hline & {$[2.33]^{*}$} & {$[1.57]$} & {$[2.12]^{*}$} & {$[2.19]^{*}$} & {$[3.74]^{\star *}$} & {$[2.85]^{\star *}$} \\
\hline DY & 0.565 & 0.66 & 0.093 & 0.124 & 0.514 & 0.581 \\
\hline & {$[4.15]^{\star \star}$} & {$[4.81]^{\star \star}$} & [1.68] & {$[2.24]^{*}$} & {$[4.12]^{\star \star}$} & {$[4.63]^{\star \star}$} \\
\hline ROE & -0.017 & -0.015 & -0.002 & -0.003 & -0.016 & -0.013 \\
\hline & {$[2.79]^{\star *}$} & {$[2.41]^{*}$} & {$[0.88]$} & {$[1.34]$} & {$[2.81]^{\star *}$} & {$[2.21]^{*}$} \\
\hline SD & -0.005 & -0.006 & -0.004 & -0.003 & -0.001 & -0.003 \\
\hline & [1.89] & {$[2.37]^{*}$} & {$[5.42]^{* *}$} & {$[4.32]^{\star \star}$} & {$[0.53]$} & [1.49] \\
\hline BDR & 0.025 & 0.026 & 0.03 & 0.023 & -0.004 & 0.006 \\
\hline & [1.06] & [1.11] & {$[3.28]^{* *}$} & {$[2.43]^{*}$} & {$[0.17]$} & {$[0.26]$} \\
\hline CASH & -0.06 & -0.063 & -0.018 & -0.018 & -0.042 & -0.046 \\
\hline & {$[2.02]^{*}$} & {$[2.11]^{*}$} & [1.93] & {$[1.92]$} & {$[1.51]$} & [1.65] \\
\hline CLOSE & -0.078 & -0.071 & -0.014 & -0.018 & -0.063 & -0.052 \\
\hline & {$[4.29]^{\star *}$} & {$[4.00]^{\star *}$} & [1.83] & {$[2.48]^{*}$} & {$[3.82]^{\star *}$} & {$[3.27]^{\star *}$} \\
\hline AUDIT & -0.056 & & -0.016 & & -0.04 & \\
\hline & {$[5.17]^{\star \star}$} & & {$[2.81]^{* *}$} & & {$[4.21]^{\star \star}$} & \\
\hline LEGAL & 0.004 & & 0.001 & & 0.004 & \\
\hline & {$[7.75]^{\star \star}$} & & {$[2.72]^{\star *}$} & & {$[7.45]^{\star \star}$} & \\
\hline BOND MARKET & 0.142 & 0.22 & 0.009 & 0.047 & 0.132 & 0.173 \\
\hline & {$[6.59]^{\star \star}$} & {$[4.91]^{\star \star}$} & {$[0.97]$} & {$[2.14]^{*}$} & {$[6.35]^{\star \star}$} & {$[4.73]^{\star *}$} \\
\hline STOCK MARKET & 0.152 & 0.179 & 0.002 & 0.048 & 0.151 & 0.134 \\
\hline & {$[9.18]^{\star *}$} & {$[9.13]^{\star *}$} & {$[0.26]$} & {$[5.57]^{\star *}$} & {$[10.45]^{\star *}$} & {$[8.07]^{* *}$} \\
\hline year dummies & yes & yes & yes & yes & yes & yes \\
\hline country dummies & no & yes & no & yes & no & yes \\
\hline Constant & 0.134 & -0.024 & 0.051 & -0.052 & 0.083 & 0.027 \\
\hline & [1.72] & {$[0.41]$} & [1.40] & {$[2.35]^{*}$} & [1.21] & [0.51] \\
\hline Observations & 13046 & 13046 & 13046 & 13046 & 13046 & 13046 \\
\hline R-squared & 0.22 & 0.23 & 0.08 & 0.11 & 0.21 & 0.22 \\
\hline
\end{tabular}

Robust t statistics in brackets

* significant at $5 \%$; ** significant at $1 \%$ 
Table 3

Determinants of domestic and foreign financial institutions

This table reports estimates of coefficients of the annual time-series cross-sectional firm-level regression of ownership for all financial institutions (FI), banks (BANK) and institutional investors (INST INV). All regressions inlcude the firm-level regressors log of total assets (LnTA), log book-to-market (BM), turnover (TURNOVER), dividend yield (DY), return on equity (ROE), standard deviation of weekly returns (SD), leverage (BDR), cash holdings (CASH) and closely held shares (CLOSE). All regressions include the country-level regressors strength of auditing and reporting (AUDIT), legal regime index (LEGAL), market capitalization of the private bond market to GDP (BOND MARKET), and market capitalization of the stock market to GDP (STOCK MARKET). Refer to Appendix A for variable definitions. The sample period is from 1997 to 2006. The robust t-statistics in parentheses are adjusted for clustering at the firm-level. Coefficients significant at the $5 \%$ level are in boldface.

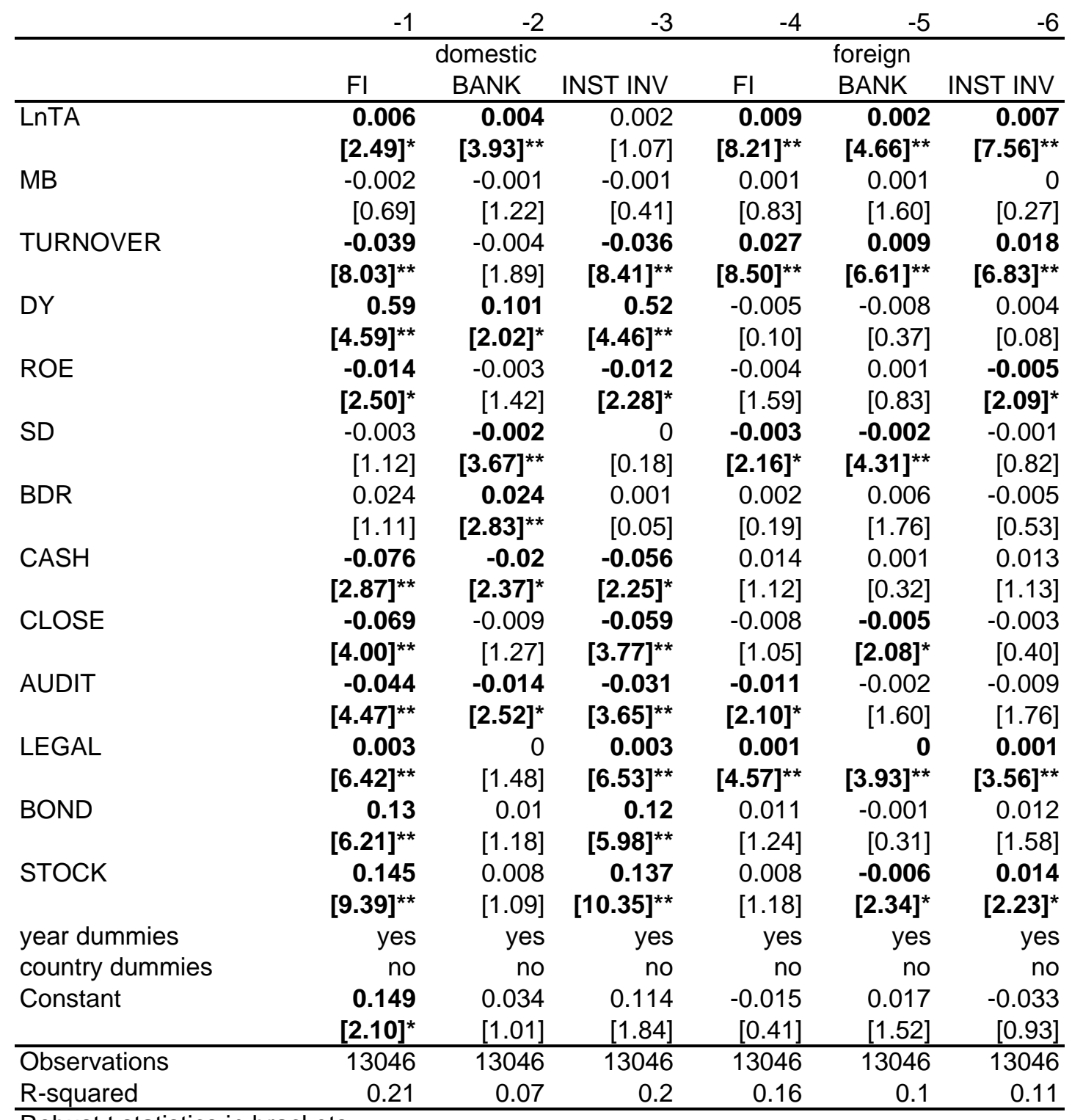

Robust t statistics in brackets

* significant at $5 \%$; ${ }^{* *}$ significant at $1 \%$ 
Table 4

\section{Institutional ownership and firm value}

This table reports estimates of coefficients of the annual time-series cross-sectional firm-level regression of Tobin's Q. Ownership include all financial institutions (FI), banks (BANK) and institutional investors (INST INV). Firm-level control variables include log total assets (LnTA), leverage (BDR), cash holdings (CASH) and European industry Tobin's Q median (Q_med). All regressions include the countrylevel regressors strength of auditing and reporting (AUDIT), legal regime index (LEGAL), market capitalization of the private bond market to GDP (BOND MARKET), and market capitalization of the stock market to GDP (STOCK MARKET). Refer to Appendix A for variable definitions. The sample period is from 1997 to 2006. The robust t-statistics in parentheses are adjusted for clustering at the firm-level. Coefficients significant at the $5 \%$ level are in boldface.

\begin{tabular}{|c|c|c|c|c|c|c|c|c|}
\hline & -1 & -2 & -3 & -4 & -5 & -6 & -7 & -8 \\
\hline & $\mathrm{Q}$ & $\mathrm{Q}$ & $\mathrm{Q}$ & $\mathrm{Q}$ & $\mathrm{Q}$ & $\mathrm{Q}$ & $\mathrm{Q}$ & $\mathrm{Q}$ \\
\hline $\mathrm{FI}$ & $\begin{array}{r}-0.044 \\
{[0.76]}\end{array}$ & $\begin{array}{r}-0.037 \\
{[0.64]}\end{array}$ & & & & & & \\
\hline BANK & & & $\begin{array}{r}-0.013 \\
{[0.10]}\end{array}$ & $\begin{array}{r}-0.126 \\
{[0.97]}\end{array}$ & & & $\begin{array}{l}0.005 \\
{[0.04]}\end{array}$ & $\begin{array}{r}-0.118 \\
{[0.91]}\end{array}$ \\
\hline INST INV & & & & & $\begin{array}{r}-0.065 \\
{[0.98]}\end{array}$ & $\begin{array}{r}-0.033 \\
{[0.50]}\end{array}$ & $\begin{array}{r}-0.065 \\
{[0.97]}\end{array}$ & $\begin{array}{r}-0.026 \\
{[0.39]}\end{array}$ \\
\hline LnTA & $\begin{array}{l}0.005 \\
{[0.54]}\end{array}$ & $\begin{array}{l}0.009 \\
{[0.95]}\end{array}$ & $\begin{array}{l}0.004 \\
{[0.48]}\end{array}$ & $\begin{array}{l}0.009 \\
{[0.96]}\end{array}$ & $\begin{array}{l}0.005 \\
{[0.54]}\end{array}$ & $\begin{array}{l}0.009 \\
{[0.93]}\end{array}$ & $\begin{array}{l}0.005 \\
{[0.53]}\end{array}$ & $\begin{array}{l}0.009 \\
{[0.97]}\end{array}$ \\
\hline BDR & $\begin{array}{r}-1.077 \\
{[12.68]^{\star *}}\end{array}$ & $\begin{array}{r}-1.098 \\
{[12.76]^{* *}}\end{array}$ & $\begin{array}{r}-1.078 \\
{[12.69]^{\star *}}\end{array}$ & $\begin{array}{r}-1.096 \\
{[12.76]^{\star *}}\end{array}$ & $\begin{array}{r}-1.079 \\
{[12.71]^{* *}}\end{array}$ & $\begin{array}{r}-1.099 \\
{[12.77]^{* *}}\end{array}$ & $\begin{array}{r}-1.079 \\
{[12.72]^{\star *}}\end{array}$ & $\begin{array}{r}-1.096 \\
{[12.77]^{\star *}}\end{array}$ \\
\hline CASH & $\begin{array}{r}1.941 \\
{[9.92]^{\star *}}\end{array}$ & $\begin{array}{r}2.029 \\
{[10.37]^{* *}}\end{array}$ & $\begin{array}{r}1.944 \\
{[9.93]^{\star *}}\end{array}$ & $\begin{array}{r}2.03 \\
{[10.37]^{* *}}\end{array}$ & $\begin{array}{r}1.941 \\
{[9.91]^{* *}}\end{array}$ & $\begin{array}{r}2.03 \\
{[10.36]^{\star \star}}\end{array}$ & $\begin{array}{r}1.941 \\
{[9.92]^{* *}}\end{array}$ & $\begin{array}{r}2.029 \\
{[10.37]^{* *}}\end{array}$ \\
\hline Q_med & $\begin{array}{r}1.088 \\
{[14.06]^{* *}}\end{array}$ & $\begin{array}{r}1.085 \\
{[14.19]^{* *}}\end{array}$ & $\begin{array}{r}1.09 \\
{[14.12]^{* *}}\end{array}$ & $\begin{array}{r}1.085 \\
{[14.23]^{* *}}\end{array}$ & $\begin{array}{r}1.088 \\
{[14.07]^{* *}}\end{array}$ & $\begin{array}{r}1.085 \\
{[14.21]^{* *}}\end{array}$ & $\begin{array}{r}1.088 \\
{[14.07]^{* *}}\end{array}$ & $\begin{array}{r}1.084 \\
{[14.20]^{* *}}\end{array}$ \\
\hline AUDIT & $\begin{array}{r}-0.05 \\
{[1.22]}\end{array}$ & & $\begin{array}{r}-0.048 \\
{[1.17]}\end{array}$ & & $\begin{array}{r}-0.05 \\
{[1.22]}\end{array}$ & & $\begin{array}{r}-0.05 \\
{[1.22]}\end{array}$ & \\
\hline LEGAL & $\begin{array}{r}-0.002 \\
{[0.84]}\end{array}$ & & $\begin{array}{r}-0.002 \\
{[0.93]}\end{array}$ & & $\begin{array}{r}-0.002 \\
{[0.81]}\end{array}$ & & $\begin{array}{r}-0.002 \\
{[0.81]}\end{array}$ & \\
\hline BOND MARKET & $\begin{array}{r}0.01 \\
{[0.11]}\end{array}$ & $\begin{array}{r}0.557 \\
{[2.73]^{\star *}}\end{array}$ & $\begin{array}{l}0.004 \\
{[0.04]}\end{array}$ & $\begin{array}{r}0.554 \\
{[2.70]^{\star *}}\end{array}$ & $\begin{array}{l}0.013 \\
{[0.13]}\end{array}$ & $\begin{array}{r}0.555 \\
{[2.72]^{\star *}}\end{array}$ & $\begin{array}{l}0.013 \\
{[0.13]}\end{array}$ & $\begin{array}{r}0.559 \\
{[2.73]^{* *}}\end{array}$ \\
\hline STOCK MARKET & $\begin{array}{r}0.245 \\
{[3.71]^{* *}}\end{array}$ & $\begin{array}{r}0.254 \\
{[3.17]^{\star *}}\end{array}$ & $\begin{array}{r}0.238 \\
{[3.62]^{\star *}}\end{array}$ & $\begin{array}{r}0.253 \\
{[3.19]^{\star *}}\end{array}$ & $\begin{array}{r}0.248 \\
{[3.73]^{\star *}}\end{array}$ & $\begin{array}{r}0.252 \\
{[3.14]^{\star *}}\end{array}$ & $\begin{array}{r}0.248 \\
{[3.73]^{\star *}}\end{array}$ & $\begin{array}{r}0.256 \\
{[3.20]^{\star *}}\end{array}$ \\
\hline $\begin{array}{l}\text { year dummies } \\
\text { country dummies }\end{array}$ & $\begin{array}{r}\text { yes } \\
\text { no }\end{array}$ & $\begin{array}{l}\text { yes } \\
\text { yes }\end{array}$ & $\begin{array}{r}\text { yes } \\
\text { no }\end{array}$ & $\begin{array}{l}\text { yes } \\
\text { yes }\end{array}$ & $\begin{array}{r}\text { yes } \\
\text { no }\end{array}$ & $\begin{array}{l}\text { yes } \\
\text { yes }\end{array}$ & $\begin{array}{r}\text { yes } \\
\text { no }\end{array}$ & $\begin{array}{l}\text { yes } \\
\text { yes }\end{array}$ \\
\hline Constant & $\begin{array}{l}0.102 \\
{[0.31]}\end{array}$ & $\begin{array}{l}-0.48 \\
{[1.81]}\end{array}$ & $\begin{array}{l}0.097 \\
{[0.30]}\end{array}$ & $\begin{array}{r}-0.486 \\
{[1.83]}\end{array}$ & $\begin{array}{r}0.1 \\
{[0.31]}\end{array}$ & $\begin{array}{r}-0.479 \\
{[1.80]}\end{array}$ & $\begin{array}{r}0.1 \\
{[0.31]}\end{array}$ & $\begin{array}{r}-0.484 \\
{[1.82]}\end{array}$ \\
\hline Observations & 13046 & 13046 & 13046 & 13046 & 13046 & 13046 & 13046 & 13046 \\
\hline R-squared & 0.22 & 0.23 & 0.21 & 0.23 & 0.22 & 0.23 & 0.22 & 0.23 \\
\hline
\end{tabular}

Robust t statistics in brackets

* significant at $5 \%$; ** significant at $1 \%$ 
Table 5

Institutional ownership and firm value

Robustness

This table reports estimates of coefficients of the annual time-series cross-sectional firm-level regression of respectively $-1 / \mathrm{Q}$, logQ and median $\mathrm{Q}$. Ownership includes all financial institutions (FI), banks (BANK) and institutional investors (INST INV). Firm-level control variables include log total assets (LnTA), leverage (BDR), cash holdings (CASH) and European industry Tobin's Q median (Q_med). All regressions include the country-level regressors strength of auditing and reporting (AUDIT), legal regime index (LEGAL), market capitalization of the private bond market to GDP (BOND MARKET), and market capitalization of the stock market to GDP (STOCK MARKET). Refer to Appendix A for variable definitions. The sample period is from 1997 to 2006. The robust t-statistics in parentheses are adjusted for clustering at the firm-level. Coefficients significant at the $5 \%$ level are in boldface.

\begin{tabular}{|c|c|c|c|c|c|c|c|c|c|}
\hline & -1 & -2 & -3 & -4 & -5 & -6 & -7 & -8 & -9 \\
\hline & & $-1 / Q$ & & & $\log Q$ & & & median Q & \\
\hline$\overline{\mathrm{FI}}$ & -0.028 & & & -0.035 & & & -0.023 & & \\
\hline & {$[2.02]^{*}$} & & & [1.51] & & & [1.10] & & \\
\hline BANK & & -0.037 & & & -0.021 & & & 0.007 & \\
\hline & & {$[1.16]$} & & & {$[0.41]$} & & & [0.13] & \\
\hline INST INV & & & -0.031 & & & -0.044 & & & -0.035 \\
\hline & & & {$[1.91]$} & & & [1.68] & & & [1.59] \\
\hline LnTA & 0.02 & 0.019 & 0.02 & 0.014 & 0.014 & 0.014 & 0.027 & 0.027 & 0.027 \\
\hline & {$[7.68]^{\star *}$} & {$[7.57]^{\star *}$} & {$[7.64]^{\star \star}$} & {$[3.61]^{\star *}$} & {$[3.51]^{\star *}$} & {$[3.61]^{\star *}$} & {$[8.85]^{\star *}$} & {$[9.06]^{\star *}$} & {$[9.06]^{\star *}$} \\
\hline BDR & -0.324 & -0.324 & -0.325 & -0.53 & -0.53 & -0.531 & -0.752 & -0.752 & -0.752 \\
\hline & {$[15.04]^{\star *}$} & {$[15.03]^{\star *}$} & {$[15.08]^{\star *}$} & {$[14.75]^{\star *}$} & {$[14.76]^{\star \star}$} & {$[14.79]^{\star \star}$} & {$[21.73]^{\star *}$} & {$[22.22]^{\star *}$} & {$[22.42]^{\star \star}$} \\
\hline CASH & 0.285 & 0.286 & 0.285 & 0.711 & 0.713 & 0.71 & 1.183 & 1.192 & 1.184 \\
\hline & {$[7.75]^{\star *}$} & {$[7.79]^{\star \star}$} & {$[7.76]^{\star \star}$} & {$[10.59]^{\star *}$} & {$[10.62]^{\star *}$} & {$[10.59]^{\star *}$} & {$[26.46]^{\star *}$} & {$[27.32]^{\star *}$} & {$[27.34]^{\star *}$} \\
\hline industry Q & 0.662 & 0.663 & 0.663 & 0.781 & 0.783 & 0.782 & 0.853 & 0.847 & 0.846 \\
\hline & {$[11.73]^{\star *}$} & {$[11.80]^{* *}$} & {$[11.76]^{\star *}$} & {$[17.38]^{\star *}$} & {$[17.48]^{\star *}$} & {$[17.39]^{\star *}$} & {$[27.19]^{* *}$} & {$[27.67]^{\star *}$} & {$[27.90]^{* *}$} \\
\hline AUDIT & -0.015 & -0.014 & -0.014 & -0.025 & -0.024 & -0.025 & & & \\
\hline & [1.31] & [1.24] & {$[1.28]$} & [1.40] & [1.32] & [1.39] & & & \\
\hline LEGAL & 0 & 0 & 0 & 0 & 0 & 0 & & & \\
\hline & {$[0.75]$} & [0.55] & {$[0.73]$} & [0.14] & [0.02] & [0.16] & & & \\
\hline BOND MARKET & 0.015 & 0.011 & 0.015 & 0.011 & 0.006 & 0.012 & 0.332 & 0.313 & 0.334 \\
\hline & {$[0.66]$} & {$[0.50]$} & [0.66] & {$[0.26]$} & [0.15] & {$[0.28]$} & {$[3.87]^{\star *}$} & {$[3.74]^{\star *}$} & {$[4.01]^{\star *}$} \\
\hline STOCK MARKET & 0.06 & 0.055 & 0.06 & 0.11 & 0.105 & 0.112 & 0.038 & 0.03 & 0.04 \\
\hline & {$[3.93]^{\star *}$} & {$[3.71]^{\star *}$} & {$[3.93]^{\star *}$} & {$[4.18]^{\star *}$} & {$[4.02]^{\star *}$} & {$[4.22]^{\star *}$} & [0.99] & [0.80] & [1.08] \\
\hline year dummies & yes & yes & yes & yes & yes & yes & yes & yes & yes \\
\hline country dummies & no & no & no & no & no & no & yes & yes & yes \\
\hline industry dummies & no & no & no & no & no & no & yes & yes & yes \\
\hline Constant & -0.501 & -0.5 & -0.501 & -0.034 & -0.036 & -0.035 & -0.785 & -0.335 & -0.763 \\
\hline & {$[5.69]^{\star *}$} & {$[5.67]^{\star *}$} & {$[5.69]^{\star \star}$} & {$[0.27]$} & {$[0.28]$} & {$[0.28]$} & {$[3.69]^{\star *}$} & {$[1.62]$} & {$[3.39]^{\star *}$} \\
\hline Observations & 13046 & 13046 & 13046 & 13025 & 13025 & 13025 & 12684 & 12684 & 12684 \\
\hline R-squared & 0.19 & 0.19 & 0.19 & 0.25 & 0.25 & 0.25 & & & \\
\hline & 0.41 & 0.41 & 0.41 & & & & & & \\
\hline
\end{tabular}

Robust t statistics in brackets

* significant at 5\%; ** significant at $1 \%$ 
Table 6

Institutional ownership and firm value

Robustness

This table reports estimates of coefficients of the annual time-series cross-sectional firm-level regression of return on assets (ROA). Ownership includes all financial institutions (FI), banks (BANK) and institutional investors (INST INV). Firm-level control variables include log total assets (LnTA), leverage (BDR), cash holdings (CASH) and European industry Tobin's Q median (Q_med). All regressions include the country-level regressors strength of auditing and reporting (AUDIT), legal regime index (LEGAL), market capitalization of the private bond market to GDP (BOND MARKET), and market capitalization of the stock market to GDP (STOCK MARKET). Refer to Appendix A for variable definitions. The sample period is from 1997 to 2006 . The robust t-statistics in parentheses are adjusted for clustering at the firm-level. Coefficients significant at the $5 \%$ level are in boldface.

\begin{tabular}{|c|c|c|c|c|c|c|}
\hline & -1 & -2 & -3 & -4 & -5 & -6 \\
\hline & ROA & ROA & $\mathrm{ROA}$ & ROA & ROA & ROA \\
\hline \multirow[t]{2}{*}{$\mathrm{FI}$} & -1.094 & -0.821 & & & & \\
\hline & {$[1.86]$} & [1.40] & & & & \\
\hline \multirow[t]{2}{*}{ BANK } & & & -2.404 & -2.864 & & \\
\hline & & & {$[2.01]^{*}$} & {$[2.37]^{*}$} & & \\
\hline \multirow[t]{2}{*}{ INST INV } & & & & & -1.037 & -0.612 \\
\hline & & & & & [1.53] & {$[0.90]$} \\
\hline \multirow[t]{2}{*}{ LnTA } & 1.568 & 1.576 & 1.566 & 1.577 & 1.562 & 1.571 \\
\hline & {$[15.19]^{\star *}$} & {$[15.10]^{\star *}$} & {$[15.16]^{\star *}$} & {$[15.15]^{\star *}$} & {$[15.20]^{\star *}$} & {$[15.10]^{\star *}$} \\
\hline \multirow[t]{2}{*}{ BDR } & -10.367 & -10.733 & -10.316 & -10.686 & -10.396 & -10.748 \\
\hline & {$[9.88]^{\star *}$} & {$[10.15]^{\star *}$} & {$[9.81]^{\star *}$} & {$[10.10]^{\star *}$} & {$[9.91]^{\star *}$} & {$[10.17]^{\star *}$} \\
\hline \multirow[t]{2}{*}{ CASH } & -4.913 & -4.767 & -4.875 & -4.757 & -4.897 & -4.745 \\
\hline & {$[2.15]^{*}$} & {$[2.05]^{*}$} & {$[2.14]^{*}$} & {$[2.05]^{*}$} & {$[2.14]^{*}$} & {$[2.04]^{*}$} \\
\hline \multirow[t]{2}{*}{ Q_med } & -1.248 & -1.184 & -1.237 & -1.189 & -1.23 & -1.167 \\
\hline & {$[2.32]^{*}$} & {$[2.22]^{*}$} & {$[2.30]^{*}$} & {$[2.23]^{*}$} & {$[2.29]^{*}$} & {$[2.19]^{\star}$} \\
\hline \multirow[t]{2}{*}{ AUDIT } & 0.508 & & 0.524 & & 0.528 & \\
\hline & [1.44] & & [1.48] & & [1.49] & \\
\hline \multirow[t]{2}{*}{ LEGAL } & -0.072 & & -0.075 & & -0.073 & \\
\hline & {$[3.77]^{\star *}$} & & {$[4.05]^{\star *}$} & & {$[3.82]^{\star *}$} & \\
\hline \multirow[t]{2}{*}{ BOND MARKET } & 0.223 & -2.469 & 0.093 & -2.528 & 0.203 & -2.54 \\
\hline & [0.25] & [1.57] & [0.11] & {$[1.60]$} & [0.23] & [1.62] \\
\hline \multirow[t]{2}{*}{ STOCK MARKET } & 1.982 & 2.519 & 1.818 & 2.507 & 1.968 & 2.455 \\
\hline & {$[3.65]^{* *}$} & {$[3.64]^{\star *}$} & {$[3.37]^{\star *}$} & {$[3.64]^{\star \star}$} & {$[3.62]^{\star *}$} & {$[3.56]^{\star *}$} \\
\hline year dummies & yes & yes & yes & yes & yes & yes \\
\hline country dummies & no & yes & no & yes & no & yes \\
\hline \multirow[t]{2}{*}{ Constant } & -23.272 & -24.146 & -23.247 & -24.283 & -23.344 & -24.125 \\
\hline & {$[8.78]^{* *}$} & {$[10.34]^{\star *}$} & {$[8.77]^{\star \star}$} & {$[10.40]^{\star *}$} & {$[8.81]^{\star *}$} & {$[10.32]^{\star *}$} \\
\hline Observations & 12996 & 12996 & 12996 & 12996 & 12996 & 12996 \\
\hline R-squared & 0.08 & 0.09 & 0.08 & 0.09 & 0.08 & 0.09 \\
\hline
\end{tabular}

Robust t statistics in brackets

* significant at $5 \%$; ** significant at $1 \%$ 
Table 7

Institutional ownership and firm value

System of ownership and firm value (Q)

This table reports estimates of coefficients of the annual time-series cross-sectional firm-level regression of Tobin's Q ; and alternatively, ownership for all financial institutions (FI) in system 1, banks (BANK) in system 2 and institutional investors (INST INV) in system 3. The system of equations is estimated using three-stage least squares. Firm-level control variables include log total assets (LnTA), turnover (TURNOVER), dividend yield (DY), return on equity (ROE), standard deviation of weekly returns(SD), leverage (BDR), cash holdings (CASH), closely held shares (CLOSE), and European industry Tobin's Q median (Q_med). All regressions include the country-level regressors strength of auditing and reporting (AUDIT), legal regime index (LEGAL), market capitalization of the private bond market to GDP (BOND MARKET), and market capitalization of the stock market to GDP (STOCK MARKET). Refer to Appendix A for variable definitions. The sample period is from 1997 to 2006. Financial and regulated firms are omitted (NACE 65-67 and 75). t-statistics are in parentheses. Coefficients significant at the 5\% level are in boldface.

\begin{tabular}{|c|c|c|c|c|c|c|}
\hline & \multicolumn{2}{|c|}{-1} & \multicolumn{2}{|c|}{-2} & \multicolumn{2}{|c|}{-3} \\
\hline & $\mathrm{Q}$ & $\mathrm{FI}$ & $\mathrm{Q}$ & BANK & $\mathrm{Q}$ & INST INV \\
\hline \multirow[t]{2}{*}{$\mathrm{FI}$} & -6.703 & & & & & \\
\hline & {$[8.89]^{\star *}$} & & & & & \\
\hline \multirow[t]{2}{*}{ BANK } & & & -6.521 & & & \\
\hline & & & {$[4.68]^{\star *}$} & & & \\
\hline \multirow[t]{2}{*}{ INST INV } & & & & & -8.681 & \\
\hline & & & & & {$[8.93]^{\star *}$} & \\
\hline \multirow[t]{2}{*}{ Q } & & -0.028 & & -0.009 & & -0.016 \\
\hline & & {$[3.18]^{\star *}$} & & {$[2.64]^{\star *}$} & & {$[2.01]^{*}$} \\
\hline \multirow[t]{2}{*}{ LnTA } & 0.107 & 0.019 & 0.042 & 0.007 & 0.088 & 0.013 \\
\hline & {$[7.19]^{\star \star}$} & {$[14.90]^{\star \star}$} & {$[4.19]^{\star \star}$} & {$[13.41]^{\star \star}$} & {$[6.29]^{\star \star}$} & {$[11.48]^{\star \star}$} \\
\hline \multirow[t]{2}{*}{ TURNOVER } & & -0.019 & & -0.005 & & -0.018 \\
\hline & & {$[7.15]^{\star \star}$} & & {$[2.91]^{\star \star}$} & & {$[6.38]^{* *}$} \\
\hline \multirow[t]{2}{*}{ DY } & & 0.696 & & 0.344 & & 0.602 \\
\hline & & {$[8.32]^{\star \star}$} & & {$[9.14]^{\star \star}$} & & {$[7.73]^{\star *}$} \\
\hline \multirow[t]{2}{*}{ ROE } & & -0.044 & & -0.022 & & -0.038 \\
\hline & & {$[9.23]^{\star *}$} & & {$[9.59]^{\star *}$} & & {$[8.81]^{* *}$} \\
\hline \multirow[t]{2}{*}{ SD } & & -0.005 & & -0.005 & & -0.004 \\
\hline & & {$[6.13]^{\star \star}$} & & {$[8.15]^{\star \star}$} & & {$[6.00]^{* *}$} \\
\hline \multirow[t]{2}{*}{ BDR } & -0.962 & -0.021 & -0.89 & 0.013 & -1.16 & -0.033 \\
\hline & {$[8.56]^{\star \star}$} & [1.18] & {$[10.95]^{\star *}$} & [1.89] & {$[9.31]^{\star *}$} & {$[2.14]^{*}$} \\
\hline \multirow[t]{2}{*}{ CASH } & 1.517 & 0.005 & 1.858 & 0.01 & 1.494 & -0.008 \\
\hline & {$[9.70]^{\star \star}$} & {$[0.21]$} & {$[19.36]^{\star *}$} & [0.98] & {$[8.62]^{\star \star}$} & [0.33] \\
\hline \multirow[t]{2}{*}{ CLOSE } & & -0.018 & & -0.01 & & -0.012 \\
\hline & & {$[2.16]^{*}$} & & {$[2.96]^{\star *}$} & & [1.83] \\
\hline \multirow[t]{2}{*}{ Q_med } & 0.787 & & 0.983 & & 0.826 & \\
\hline & {$[10.92]^{\star *}$} & & {$[21.20]^{\star *}$} & & {$[10.77]^{\star *}$} & \\
\hline \multirow[t]{2}{*}{ AUDIT } & -0.388 & -0.058 & -0.154 & -0.018 & -0.349 & -0.041 \\
\hline & {$[5.93]^{\star *}$} & {$[8.50]^{\star *}$} & {$[3.80]^{\star *}$} & {$[6.58]^{\star *}$} & {$[5.13]^{\star *}$} & {$[6.75]^{* *}$} \\
\hline \multirow[t]{2}{*}{ LEGAL } & 0.03 & 0.005 & 0.002 & 0.001 & 0.034 & 0.004 \\
\hline & {$[6.85]^{\star \star}$} & {$[15.11]^{\star \star}$} & [1.27] & {$[5.48]^{\star \star}$} & {$[6.96]^{\star *}$} & {$[15.01]^{\star *}$} \\
\hline \multirow[t]{2}{*}{ BOND MARKET } & 0.976 & 0.146 & 0.079 & 0.011 & 1.156 & 0.134 \\
\hline & {$[6.44]^{\star *}$} & {$[10.91]^{\star *}$} & [1.16] & {$[1.98]^{*}$} & {$[6.64]^{* *}$} & {$[11.30]^{\star *}$} \\
\hline \multirow[t]{2}{*}{ STOCK MARKET } & 1.32 & 0.171 & 0.273 & 0.008 & 1.599 & 0.164 \\
\hline & {$[9.08]^{\star \star}$} & {$[16.47]^{\star *}$} & {$[5.36]^{\star \star}$} & [1.79] & {$[9.07]^{\star *}$} & {$[17.83]^{\star *}$} \\
\hline year dummies & yes & yes & yes & yes & yes & yes \\
\hline \multirow[t]{2}{*}{ Constant } & 0.92 & 0.069 & 0.537 & 0.039 & 0.622 & 0.011 \\
\hline & {$[2.52]^{*}$} & [1.43] & {$[2.21]^{*}$} & [1.92] & [1.56] & [0.25] \\
\hline Observations & 13046 & 13046 & 13046 & 13046 & 13046 & 13046 \\
\hline
\end{tabular}

Absolute value of $z$ statistics in brackets

* significant at $5 \%$; ** significant at $1 \%$ 
Table 8

Institutional ownership and firm value

System of ownership and firm value (logQ)

This table reports estimates of coefficients of the annual time-series cross-sectional firm-level regression of log Tobin's $Q$ $(\log (\mathrm{Q})$; and alternatively, ownershipfor all financial institutions $(\mathrm{FI})$ in system 1, banks (BANK) in system 2 and institutional investors (INST INV) in system 3. The system of equations is estimated using three-stage least squares. Firm-level control variables include log total assets (LnTA), turnover (TURNOVER), dividend yield (DY), return on equity (ROE), standard deviation of weekly returns(SD), leverage (BDR), cash holdings (CASH), closely held shares (CLOSE), and European industry Tobin's Q median (logQ_med). All regressions include the country-level regressors strength of auditing and reporting (AUDIT), legal regime index (LEGAL), market capitalization of the private bond market to GDP (BOND MARKET), and market capitalization of the stock market to GDP (STOCK MARKET). Refer to Appendix A for variable definitions. The sample period is from 1997 to 2006 . tstatistics are in parentheses. Coefficients significant at the $5 \%$ level are in boldface.

\begin{tabular}{|c|c|c|c|c|c|c|}
\hline & \multicolumn{2}{|c|}{-1} & \multicolumn{2}{|c|}{-2} & \multicolumn{2}{|c|}{-3} \\
\hline \multirow{3}{*}{$\overline{\mathrm{FI}}$} & $\log Q$ & $\mathrm{FI}$ & $\log \mathrm{Q}$ & BANK & $\log \mathrm{Q}$ & INST INV \\
\hline & -2.704 & & & & & \\
\hline & {$[9.11]^{\star *}$} & & & & & \\
\hline \multirow[t]{2}{*}{ BANK } & & & -3.183 & & & \\
\hline & & & {$[5.61]^{\star *}$} & & & \\
\hline \multirow[t]{2}{*}{ INST INV } & & & & & -3.431 & \\
\hline & & & & & {$[9.05]^{\star \star}$} & \\
\hline \multirow[t]{2}{*}{$\log Q$} & & -0.076 & & -0.025 & & -0.043 \\
\hline & & {$[3.57]^{\star *}$} & & {$[2.84]^{\star *}$} & & {$[2.28]^{*}$} \\
\hline \multirow[t]{2}{*}{ LnTA } & 0.055 & 0.02 & 0.032 & 0.008 & 0.046 & 0.014 \\
\hline & {$[9.37]^{\star *}$} & {$[16.48]^{\star *}$} & {$[7.84]^{\star *}$} & {$[15.60]^{\star *}$} & {$[8.51]^{\star *}$} & {$[12.71]^{\star *}$} \\
\hline \multirow[t]{2}{*}{ TURNOVER } & & -0.018 & & -0.006 & & -0.017 \\
\hline & & {$[7.07]^{\star *}$} & & {$[3.78]^{\star *}$} & & {$[6.28]^{\star *}$} \\
\hline \multirow[t]{2}{*}{ DY } & & 0.639 & & 0.341 & & 0.564 \\
\hline & & {$[8.14]^{\star \star}$} & & {$[10.13]^{\star \star}$} & & {$[7.64]^{\star *}$} \\
\hline \multirow[t]{2}{*}{ ROE } & & -0.052 & & -0.028 & & -0.046 \\
\hline & & {$[9.74]^{\star *}$} & & {$[11.88]^{\star \star}$} & & {$[9.44]^{\star *}$} \\
\hline \multirow[t]{2}{*}{ SD } & & -0.006 & & -0.005 & & -0.005 \\
\hline & & {$[6.78]^{\star *}$} & & {$[8.64]^{\star *}$} & & {$[6.89]^{* *}$} \\
\hline \multirow[t]{2}{*}{ BDR } & -0.487 & -0.036 & -0.44 & 0.008 & -0.566 & -0.043 \\
\hline & {$[11.00]^{\star *}$} & {$[1.96]$} & {$[13.26]^{\star *}$} & [1.05] & {$[11.64]^{\star *}$} & {$[2.66]^{* *}$} \\
\hline \multirow[t]{2}{*}{$\mathrm{CASH}$} & 0.536 & 0.002 & 0.671 & 0.01 & 0.529 & -0.01 \\
\hline & {$[8.66]^{\star *}$} & {$[0.08]$} & {$[17.01]^{\star *}$} & {$[0.94]$} & {$[7.80]^{\star *}$} & [0.47] \\
\hline \multirow[t]{2}{*}{ CLOSE } & & -0.014 & & -0.007 & & -0.01 \\
\hline & & {$[1.72]$} & & {$[2.33]^{*}$} & & [1.46] \\
\hline \multirow[t]{2}{*}{ logQ_med } & 0.556 & & 0.687 & & 0.59 & \\
\hline & {$[10.87]^{\star *}$} & & {$[20.09]^{\star *}$} & & {$[11.01]^{\star *}$} & \\
\hline \multirow[t]{2}{*}{ AUDIT } & -0.159 & -0.057 & -0.075 & -0.019 & -0.141 & -0.04 \\
\hline & {$[6.21]^{\star *}$} & {$[8.46]^{\star *}$} & {$[4.52]^{\star *}$} & {$[6.67]^{\star \star}$} & {$[5.35]^{\star *}$} & {$[6.70]^{\star *}$} \\
\hline \multirow[t]{2}{*}{ LEGAL } & 0.013 & 0.005 & 0.002 & 0.001 & 0.014 & 0.004 \\
\hline & {$[7.50]^{\star *}$} & {$[15.42]^{\star *}$} & {$[2.87]^{\star *}$} & {$[5.77]^{\star *}$} & {$[7.49]^{\star *}$} & {$[15.23]^{\star *}$} \\
\hline \multirow[t]{2}{*}{ BOND MARKET } & 0.397 & 0.146 & 0.042 & 0.011 & 0.461 & 0.134 \\
\hline & {$[6.67]^{\star *}$} & {$[10.93]^{\star *}$} & [1.51] & {$[2.03]^{*}$} & {$[6.80]^{* *}$} & {$[11.30]^{* *}$} \\
\hline \multirow[t]{2}{*}{ STOCK MARKET } & 0.542 & 0.173 & 0.122 & 0.009 & 0.643 & 0.165 \\
\hline & {$[9.46]^{\star *}$} & {$[16.73]^{\star *}$} & {$[5.83]^{\star *}$} & {$[2.14]^{*}$} & {$[9.36]^{\star *}$} & {$[18.02]^{\star *}$} \\
\hline year dummies & yes & yes & yes & yes & yes & yes \\
\hline \multirow[t]{2}{*}{ Constant } & 0.21 & 0.03 & 0.139 & 0.018 & 0.1 & -0.016 \\
\hline & [1.52] & [0.65] & [1.47] & {$[0.97]$} & [0.67] & {$[0.38]$} \\
\hline Observations & 13025 & 13025 & 13025 & 13025 & 13025 & 13025 \\
\hline
\end{tabular}

Absolute value of $z$ statistics in brackets

* significant at $5 \%$; ** significant at $1 \%$ 
Table 9

Institutional ownership and firm value

System of ownership and firm value (ROA)

This table reports estimates of coefficients of the annual time-series cross-sectional firm-level regression of ROA; and alternatively, ownership for all financial institutions (FI) in system 1, banks (BANK) in system 2 and institutional investors (INST INV) in system 3. The system of equations is estimated using three-stage least squares. Firm-level control variables include log total assets (LnTA), turnover (TURNOVER), dividend yield (DY), return on equity (ROE), standard deviation of weekly returns(SD), leverage (BDR), cash holdings (CASH), closely held shares (CLOSE), and European industry ROA median (ROA_med). All regressions include the country-level regressors strength of auditing and reporting (AUDIT), legal regime index (LEGAL), market capitalization of the private bond market to GDP (BOND MARKET), and market capitalization of the stock market to GDP (STOCK MARKET). Refer to Appendix A for variable definitions. The sample period is from 1997 to 2006 . tstatistics are in parentheses. Coefficients significant at the $5 \%$ level are in boldface.

\begin{tabular}{|c|c|c|c|c|c|c|}
\hline & \multicolumn{2}{|c|}{-1} & \multicolumn{2}{|c|}{-2} & \multicolumn{2}{|c|}{-3} \\
\hline & ROA & $\mathrm{FI}$ & ROA & BANK & $\mathrm{ROA}$ & INST INV \\
\hline \multirow[t]{2}{*}{$\overline{\mathrm{FI}}$} & -62.701 & & & & & \\
\hline & {$[8.63]^{\star *}$} & & & & & \\
\hline \multirow[t]{2}{*}{ BANK } & & & -192.328 & & & \\
\hline & & & {$[7.33]^{\star \star}$} & & & \\
\hline \multirow[t]{2}{*}{ INST INV } & & & & & -61.591 & \\
\hline & & & & & {$[7.86]^{\star *}$} & \\
\hline \multirow[t]{2}{*}{ ROA } & & 0.01 & & 0.002 & & 0.01 \\
\hline & & {$[4.54]^{\star *}$} & & {$[2.27]^{*}$} & & {$[4.96]^{* *}$} \\
\hline \multirow[t]{2}{*}{ LnTA } & 2.341 & 0.011 & 2.518 & 0.006 & 1.976 & 0.005 \\
\hline & {$[16.44]^{\star \star}$} & {$[4.27]^{\star *}$} & {$[13.55]^{\star *}$} & {$[6.00]^{\star *}$} & {$[17.59]^{\star *}$} & {$[2.09]^{*}$} \\
\hline \multirow[t]{2}{*}{ TURNOVER } & & 0.014 & & 0.007 & & 0.009 \\
\hline & & {$[3.39]^{\star *}$} & & {$[5.11]^{\star *}$} & & {$[2.21]^{*}$} \\
\hline \multirow[t]{2}{*}{ DY } & & -0.011 & & -0.05 & & 0.022 \\
\hline & & {$[0.14]$} & & {$[2.15]^{*}$} & & {$[0.30]$} \\
\hline \multirow[t]{2}{*}{ ROE } & & -0.263 & & -0.078 & & -0.247 \\
\hline & & {$[8.71]^{\star *}$} & & {$[6.52]^{\star *}$} & & {$[9.06]^{\star *}$} \\
\hline \multirow[t]{2}{*}{ SD } & & -0.006 & & -0.002 & & -0.004 \\
\hline & & {$[4.59]^{\star *}$} & & {$[3.86]^{\star *}$} & & {$[3.47]^{\star *}$} \\
\hline \multirow[t]{2}{*}{ BDR } & -8.59 & 0.043 & -4.08 & 0.026 & -10.431 & 0.018 \\
\hline & {$[7.69]^{\star \star}$} & {$[2.24]^{*}$} & {$[2.67]^{\star *}$} & {$[3.38]^{\star *}$} & {$[10.23]^{\star *}$} & [1.06] \\
\hline \multirow[t]{2}{*}{$\mathrm{CASH}$} & -7.973 & -0.052 & -6.964 & -0.018 & -6.882 & -0.032 \\
\hline & {$[5.10]^{\star *}$} & {$[2.54]^{*}$} & {$[3.91]^{\star *}$} & {$[2.17]^{*}$} & {$[4.81]^{\star *}$} & {$[1.76]$} \\
\hline \multirow[t]{2}{*}{ CLOSE } & & -0.06 & & -0.012 & & -0.057 \\
\hline & & {$[6.30]^{\star *}$} & & {$[4.08]^{\star *}$} & & {$[6.55]^{\star *}$} \\
\hline \multirow[t]{2}{*}{ ROA_med } & 1.843 & & 1.462 & & 1.9 & \\
\hline & {$[11.17]^{\star *}$} & & {$[7.66]^{\star \star}$} & & {$[12.25]^{\star *}$} & \\
\hline \multirow[t]{2}{*}{ AUDIT } & -2.791 & -0.048 & -2.778 & -0.015 & -1.687 & -0.033 \\
\hline & {$[4.29]^{\star *}$} & {$[7.10]^{\star *}$} & {$[3.65]^{\star *}$} & {$[5.34]^{\star *}$} & {$[3.00]^{\star *}$} & {$[5.38]^{\star *}$} \\
\hline \multirow[t]{2}{*}{ LEGAL } & 0.224 & 0.005 & 0.055 & 0.001 & 0.183 & 0.004 \\
\hline & {$[5.33]^{\star *}$} & {$[14.65]^{\star *}$} & [1.68] & {$[4.97]^{* *}$} & {$[4.64]^{\star *}$} & {$[14.41]^{\star *}$} \\
\hline \multirow[t]{2}{*}{ BOND MARKET } & 9.248 & 0.139 & 2.377 & 0.01 & 8.32 & 0.127 \\
\hline & {$[6.24]^{\star *}$} & {$[10.31]^{\star *}$} & [1.91] & {$[1.76]$} & {$[5.87]^{\star *}$} & {$[10.53]^{* *}$} \\
\hline \multirow[t]{2}{*}{ STOCK MARKET } & 11.702 & 0.14 & 2.648 & 0.001 & 11.23 & 0.136 \\
\hline & {$[8.30]^{\star \star}$} & {$[12.63]^{\star *}$} & {$[2.85]^{\star *}$} & {$[0.22]$} & {$[7.88]^{\star *}$} & {$[13.68]^{\star *}$} \\
\hline \multicolumn{7}{|l|}{ year dummies } \\
\hline \multirow[t]{2}{*}{ Constant } & -27.431 & 0.115 & -21.494 & 0.026 & -30.191 & 0.086 \\
\hline & {$[8.02]^{\star *}$} & {$[2.13]^{*}$} & {$[5.18]^{\star \star}$} & [1.21] & {$[9.58]^{\star *}$} & [1.78] \\
\hline Observations & 12996 & 12996 & 12996 & 12996 & 12996 & 12996 \\
\hline
\end{tabular}

Absolute value of $z$ statistics in brackets

* significant at $5 \%$; ** significant at $1 \%$ 
Table 10

Institutional ownership and firm value

System of ownership, firm value (Q) and leverage

This table reports estimates of coefficients of the annual time-series cross-sectional firm-level regression of Tobin's Q, leverage (BDR); and alternatively, ownershipfor all financial institutions (FI) in system 1, banks (BANK) in system 2 and institutional investors (INST INV) in system 3. The system of equations is estimated using three-stage least squares. Firm-level control variables include log total assets (LnTA), turnover (TURNOVER), dividend yield (DY), return on equity (ROE), standard deviation of weekly returns(SD), cash holdings (CASH), closely held shares (CLOSE), European industry Tobin's Q median (Q med), fixed assets proportion (FA TA), profitability (EBIT TA), depreciation (DEP TA) and European leverage median (BDR_med). All regressions include the country-level regressors strength of auditing and reporting (AUDIT), legal regime index (LEGAL), market capitalization of the private bond market to GDP (BOND MARKET), and market capitalization of the stock market to GDP (STOCK MARKET). Refer to Appendix A for variable definitions. The sample period is from 1997 to 2006. t-statistics are in parentheses. Coefficients significant at the $5 \%$ level are in boldface.

\begin{tabular}{|c|c|c|c|c|c|c|c|c|c|}
\hline & & -1 & & & -2 & & & -3 & \\
\hline & Q & $\mathrm{FI}$ & BDR & Q & BANK & BDR & Q & INST INV & BDR \\
\hline $\mathrm{FI}$ & -8.856 & & 0.903 & & & & & & \\
\hline & {$[14.17]^{\star \star}$} & & {$[14.40]^{\star *}$} & & & & & & \\
\hline BANK & & & & -17.339 & & 2.471 & & & \\
\hline & & & & {$[11.52]^{* *}$} & & {$[15.92]^{\star *}$} & & & \\
\hline INST INV & & & & & & & -10.567 & & 1.09 \\
\hline & & & & & & & {$[14.59]^{\star \star}$} & & {$[11.74]^{\star \star *}$} \\
\hline Q & & -0.092 & 0.098 & & -0.039 & 0.105 & & -0.078 & 0.097 \\
\hline & & {$[25.00]^{\star *}$} & {$[18.26]^{\star *}$} & & {$[22.24]^{\star *}$} & {$[20.99]^{\star *}$} & & {$[22.73]^{\star *}$} & {$[16.52]^{\star \star}$} \\
\hline BDR & -2.477 & -0.269 & & -1.836 & -0.085 & & -3.12 & -0.295 & \\
\hline & {$[7.98]^{\star *}$} & {$[6.49]^{\star *}$} & & {$[6.73]^{\star *}$} & {$[4.83]^{\star *}$} & & {$[9.81]^{\star \star}$} & {$[7.94]^{\star *}$} & \\
\hline LnTA & 0.184 & 0.023 & & 0.134 & 0.009 & & 0.175 & 0.02 & \\
\hline & {$[14.89]^{\star \star}$} & {$[18.45]^{\star *}$} & & {$[13.17]^{\star *}$} & {$[17.60]^{\star *}$} & & {$[15.59]^{* *}$} & {$[17.93]^{\star *}$} & \\
\hline TURNOVER & & -0.001 & & & -0.002 & & & 0 & \\
\hline & & [0.39] & & & [1.77] & & & {$[0.21]$} & \\
\hline DY & & 0.024 & & & 0.031 & & & 0.001 & \\
\hline & & {$[0.46]$} & & & [1.67] & & & {$[0.02]$} & \\
\hline ROE & & -0.017 & & & -0.01 & & & -0.015 & \\
\hline & & {$[6.25]^{\star *}$} & & & {$[9.55]^{\star \star}$} & & & {$[5.85]^{\star *}$} & \\
\hline SD & & -0.002 & & & -0.001 & & & -0.002 & \\
\hline & & {$[2.86]^{\star *}$} & & & {$[2.52]^{*}$} & & & {$[3.33]^{* *}$} & \\
\hline CASH & 0.9 & 0.065 & -0.527 & 1.322 & 0.046 & -0.55 & 0.826 & 0.047 & -0.544 \\
\hline & {$[4.55]^{\star *}$} & {$[2.57]^{*}$} & {$[25.18]^{\star *}$} & {$[8.44]^{\star *}$} & {$[4.45]^{\star *}$} & {$[26.23]^{\star *}$} & {$[4.04]^{\star *}$} & {$[2.11]^{*}$} & {$[24.93]^{\star \star}$} \\
\hline Q_med & 0.283 & & & 0.433 & & & 0.319 & & \\
\hline & {$[6.16]^{\star *}$} & & & {$[10.55]^{* *}$} & & & {$[6.92]^{\star *}$} & & \\
\hline
\end{tabular}


Table 10

Institutional ownership and firm value

System of ownership, firm value (Q) and leverage

\begin{tabular}{|c|c|c|c|c|c|c|c|c|c|}
\hline & \multicolumn{3}{|c|}{-1} & \multicolumn{3}{|c|}{-2} & \multicolumn{3}{|c|}{-3} \\
\hline \multirow{3}{*}{$\overline{C L O S E}$} & $\mathrm{Q}$ & $\mathrm{FI}$ & BDR & $\mathrm{Q}$ & BANK & BDR & $\mathrm{Q}$ & INST INV & BDR \\
\hline & & 0.009 & & & 0.004 & & & $\begin{array}{r}0.01 \\
1.751\end{array}$ & \\
\hline & & [1.46] & 0.148 & & [2.14] $]^{*}$ & 0.136 & & [1.75] & 0.158 \\
\hline FA_TA & & & {$[20.10]^{\star *}$} & & & {$[18.85]^{\star *}$} & & & {$[20.09]^{\star \star}$} \\
\hline \multirow[t]{2}{*}{ DEP_TA } & & & -0.278 & & & -0.246 & & & -0.309 \\
\hline & & & {$[7.23]^{* *}$} & & & {$[7.29]^{\star *}$} & & & {$[7.20]^{\star *}$} \\
\hline \multirow[t]{2}{*}{ EBIT_TA } & & & -0.302 & & & -0.288 & & & -0.312 \\
\hline & & & {$[18.25]^{\star *}$} & & & {$[19.35]^{\star *}$} & & & {$[17.24]^{\star \star}$} \\
\hline \multirow[t]{2}{*}{ BDR_med } & & & 0.518 & & & 0.493 & & & 0.543 \\
\hline & & & {$[21.17]^{\star *}$} & & & {$[20.78]^{\star \star}$} & & & {$[21.34]^{\star \star}$} \\
\hline \multirow[t]{2}{*}{ AUDIT } & -0.421 & -0.046 & 0.093 & -0.267 & -0.015 & 0.085 & -0.32 & -0.028 & 0.085 \\
\hline & {$[6.67]^{\star *}$} & {$[6.72]^{\star *}$} & {$[12.61]^{\star *}$} & {$[5.21]^{\star \star}$} & {$[5.26]^{\star \star}$} & {$[12.13]^{\star *}$} & {$[5.27]^{\star \star}$} & {$[4.61]^{\star \star}$} & {$[11.15]^{\star *}$} \\
\hline \multirow[t]{2}{*}{ LEGAL } & 0.039 & 0.005 & -0.006 & 0.009 & 0.001 & -0.003 & 0.041 & 0.004 & -0.006 \\
\hline & {$[10.19]^{\star *}$} & {$[14.55]^{\star *}$} & {$[13.93]^{\star *}$} & {$[4.02]^{\star *}$} & {$[4.75]^{\star *}$} & {$[9.85]^{* \star}$} & {$[10.51]^{\star *}$} & {$[14.34]^{\star *}$} & {$[12.43]^{\star *}$} \\
\hline \multirow[t]{2}{*}{ BOND MARKET } & 1.175 & 0.132 & -0.215 & 0.112 & 0.007 & -0.108 & 1.267 & 0.119 & -0.231 \\
\hline & {$[8.34]^{\star *}$} & {$[9.78]^{\star *}$} & {$[13.66]^{\star *}$} & {$[1.26]$} & [1.27] & {$[8.38]^{* *}$} & {$[8.72]^{\star *}$} & {$[9.85]^{\star *}$} & {$[12.61]^{\star \star}$} \\
\hline \multirow[t]{2}{*}{ STOCK MARKET } & 1.661 & 0.186 & -0.165 & 0.324 & 0.016 & -0.033 & 1.889 & 0.177 & -0.189 \\
\hline & {$[12.92]^{\star *}$} & {$[18.29]^{\star *}$} & {$[11.38]^{* *}$} & {$[5.01]^{\star *}$} & {$[3.88]^{\star *}$} & {$[3.38]^{\star *}$} & {$[13.51]^{\star *}$} & {$[19.59]^{\star *}$} & {$[10.35]^{\star *}$} \\
\hline year dummies & yes & yes & yes & yes & yes & yes & yes & yes & yes \\
\hline \multirow[t]{2}{*}{ Constant } & 1.058 & 0.078 & -0.524 & 1.338 & 0.058 & -0.596 & 0.214 & -0.032 & -0.426 \\
\hline & {$[2.95]^{\star *}$} & [1.83] & {$[11.69]^{* *}$} & {$[4.37]^{\star *}$} & {$[3.32]^{\star *}$} & {$[13.13]^{\star *}$} & {$[0.60]$} & {$[0.86]$} & {$[9.56]^{\star *}$} \\
\hline Observations & 13046 & 13046 & 13046 & 13046 & 13046 & 13046 & 13046 & 13046 & 13046 \\
\hline
\end{tabular}

Absolute value of $z$ statistics in brackets

* significant at $5 \%$; ** significant at $1 \%$ 
Table 11

Institutional ownership and firm value

System of ownership, firm value (logQ) and leverage

This table reports estimates of coefficients of the annual time-series cross-sectional firm-level regression of log Tobin's Q (log(Q), leverage (BDR); and alternatively, ownership for all financial institutions (FI) in system 1, banks (BANK) in system 2 and institutional investors (INST INV) in system 3 . The system of equations is estimated using three-stage least squares. Firm-level control variables include log total assets (LnTA), turnover (TURNOVER), dividend yield (DY), return on equity (ROE), standard deviation of weekly returns(SD), cash holdings (CASH), closely held shares (CLOSE), European industry log Tobin's Q median (logQ med), fixed assets proportion (FA TA), profitability (EBIT TA), depreciation (DEP TA) and European leverage median (BDR_med). All regressions include the country-level regressors strength of auditing and reporting (AUDIT), legal regime index (LEGAL), market capitalization of the private bond market to GDP (BOND MARKET), and market capitalization of the stock market to GDP (STOCK MARKET). Refer to Appendix A for variable definitions. The sample period is from 1997 to 2006. t-statistics are in parentheses. Coefficients significant at the $5 \%$ level are in boldface.

\begin{tabular}{|c|c|c|c|c|c|c|c|c|c|}
\hline & \multicolumn{3}{|c|}{-1} & \multicolumn{3}{|c|}{-2} & \multicolumn{3}{|c|}{-3} \\
\hline & $\log Q$ & $\mathrm{FI}$ & BDR & $\log Q$ & BANK & BDR & $\log Q$ & INST INV & BDR \\
\hline \multirow[t]{2}{*}{$\overline{\mathrm{FI}}$} & -3.397 & & 0.774 & & & & & & \\
\hline & {$[13.14]^{\star *}$} & & {$[13.19]^{\star *}$} & & & & & & \\
\hline \multirow[t]{2}{*}{ BANK } & & & & -7.271 & & 2.166 & & & \\
\hline & & & & {$[11.58]^{\star *}$} & & {$[14.65]^{\star *}$} & & & \\
\hline \multirow[t]{2}{*}{ INST INV } & & & & & & & -3.947 & & 0.945 \\
\hline & & & & & & & {$[13.53]^{\star *}$} & & {$[10.85]^{\star *}$} \\
\hline \multirow[t]{2}{*}{$\log Q$} & & -0.236 & 0.226 & & -0.103 & 0.251 & & -0.202 & 0.231 \\
\hline & & {$[28.86]^{\star *}$} & {$[17.58]^{\star *}$} & & {$[26.89]^{\star *}$} & {$[21.37]^{\star \star}$} & & {$[26.36]^{\star *}$} & {$[16.57]^{\star *}$} \\
\hline \multirow[t]{2}{*}{ BDR } & -1.308 & -0.354 & & -0.998 & -0.117 & & -1.556 & -0.375 & \\
\hline & {$[10.49]^{\star *}$} & {$[8.55]^{\star *}$} & & {$[8.66]^{\star \star}$} & {$[6.75]^{\star *}$} & & {$[12.41]^{\star *}$} & {$[10.06]^{\star *}$} & \\
\hline \multirow[t]{2}{*}{ LnTA } & 0.085 & 0.027 & & 0.069 & 0.01 & & 0.08 & 0.022 & \\
\hline & {$[16.51]^{\star *}$} & {$[21.06]^{\star *}$} & & {$[16.05]^{\star \star}$} & {$[20.03]^{\star *}$} & & {$[17.37]^{\star \star}$} & {$[20.29]^{\star *}$} & \\
\hline \multirow[t]{2}{*}{ TURNOVER } & & -0.001 & & & -0.001 & & & 0 & \\
\hline & & [0.45] & & & [1.20] & & & [0.09] & \\
\hline \multirow[t]{2}{*}{ DY } & & 0.026 & & & 0.019 & & & 0.011 & \\
\hline & & [0.52] & & & [1.16] & & & {$[0.22]$} & \\
\hline \multirow[t]{2}{*}{ ROE } & & -0.019 & & & -0.01 & & & -0.018 & \\
\hline & & {$[7.10]^{\star \star}$} & & & {$[9.85]^{\star *}$} & & & {$[6.85]^{\star *}$} & \\
\hline \multirow[t]{2}{*}{ SD } & & -0.002 & & & -0.001 & & & -0.002 & \\
\hline & & {$[3.47]^{\star *}$} & & & {$[2.98]^{\star *}$} & & & {$[3.90]^{\star *}$} & \\
\hline \multirow[t]{2}{*}{$\mathrm{CASH}$} & 0.208 & 0.027 & -0.507 & 0.393 & 0.034 & -0.537 & 0.178 & 0.015 & -0.528 \\
\hline & {$[2.60]^{\star \star}$} & [1.08] & {$[25.13]^{\star *}$} & {$[5.86]^{\star *}$} & {$[3.29]^{\star *}$} & {$[26.59]^{\star *}$} & {$[2.21]^{*}$} & [0.65] & {$[25.06]^{\star *}$} \\
\hline \multirow[t]{2}{*}{ logQ_med } & 0.191 & & & 0.247 & & & 0.221 & & \\
\hline & {$[5.83]^{\star *}$} & & & {$[8.60]^{\star \star}$} & & & {$[6.89]^{\star \star}$} & & \\
\hline
\end{tabular}


Table 11

Institutional ownership and firm value

System of ownership, firm value (logQ) and leverage

\begin{tabular}{|c|c|c|c|c|c|c|c|c|c|}
\hline & \multicolumn{3}{|c|}{-1} & \multicolumn{3}{|c|}{-2} & \multicolumn{3}{|c|}{-3} \\
\hline \multirow{3}{*}{ CLOSE } & $\log \mathrm{Q}$ & $\mathrm{FI}$ & BDR & $\log Q$ & BANK & BDR & $\log \mathrm{Q}$ & INST INV & BDR \\
\hline & & 0.007 & & & 0.004 & & & 0.008 & \\
\hline & & [1.02] & & & {$[2.01]^{*}$} & & & [1.33] & \\
\hline \multirow[t]{2}{*}{ FA_TA } & & & 0.151 & & & 0.142 & & & 0.161 \\
\hline & & & {$[20.96]^{\star \star}$} & & & {$[19.78]^{\star \star}$} & & & {$[20.93]^{\star \star}$} \\
\hline \multirow{2}{*}{ DEP_TA } & & & -0.3 & & & -0.28 & & & -0.331 \\
\hline & & & {$[7.69]^{\star \star}$} & & & {$[8.12]^{\star \star}$} & & & {$[7.62]^{\star \star}$} \\
\hline \multirow[t]{2}{*}{ EBIT_TA } & & & -0.323 & & & -0.315 & & & -0.337 \\
\hline & & & {$[17.98]^{\star *}$} & & & {$[19.49]^{\star *}$} & & & {$[17.21]^{\star \star}$} \\
\hline \multirow[t]{2}{*}{ BDR_med } & & & 0.536 & & & 0.517 & & & 0.564 \\
\hline & & & {$[22.03]^{\star *}$} & & & {$[22.03]^{\star *}$} & & & {$[22.16]^{\star *}$} \\
\hline \multirow[t]{2}{*}{ AUDIT } & -0.156 & -0.044 & 0.087 & -0.108 & -0.014 & 0.082 & -0.113 & -0.027 & 0.081 \\
\hline & {$[6.13]^{\star *}$} & {$[6.49]^{* *}$} & {$[12.38]^{\star \star}$} & {$[4.96]^{\star \star}$} & {$[5.04]^{\star *}$} & {$[12.01]^{\star *}$} & {$[4.75]^{\star \star}$} & {$[4.38]^{\star \star}$} & {$[11.05]^{\star *}$} \\
\hline \multirow[t]{2}{*}{ LEGAL } & 0.016 & 0.005 & -0.005 & 0.005 & 0.001 & -0.003 & 0.016 & 0.004 & -0.006 \\
\hline & {$[9.94]^{* *}$} & {$[15.00]^{\star *}$} & {$[13.58]^{\star *}$} & {$[4.73]^{\star \star}$} & {$[5.22]^{\star *}$} & {$[10.30]^{\star *}$} & {$[10.18]^{\star \star}$} & {$[14.72]^{\star *}$} & {$[12.15]^{\star \star}$} \\
\hline \multirow[t]{2}{*}{ BOND MARKET } & 0.437 & 0.129 & -0.198 & 0.04 & 0.006 & -0.108 & 0.458 & 0.115 & -0.213 \\
\hline & {$[7.66]^{* \star}$} & {$[9.52]^{* *}$} & {$[13.19]^{\star *}$} & {$[1.05]$} & [1.04] & {$[8.56]^{\star *}$} & {$[7.95]^{\star *}$} & {$[9.56]^{\star *}$} & {$[12.20]^{\star *}$} \\
\hline \multirow[t]{2}{*}{ STOCK MARKET } & 0.651 & 0.188 & -0.144 & 0.141 & 0.017 & -0.033 & 0.722 & 0.18 & -0.167 \\
\hline & {$[12.39]^{\star *}$} & {$[18.59]^{\star *}$} & {$[10.47]^{\star *}$} & {$[5.10]^{\star \star}$} & {$[4.19]^{\star *}$} & {$[3.40]^{\star *}$} & {$[12.92]^{\star *}$} & {$[19.91]^{\star *}$} & {$[9.64]^{\star *}$} \\
\hline \multicolumn{10}{|l|}{ year dummies } \\
\hline \multirow[t]{2}{*}{ Constant } & 0.067 & -0.024 & -0.425 & 0.269 & 0.018 & -0.498 & -0.219 & -0.111 & -0.348 \\
\hline & {$[0.47]$} & {$[0.56]$} & {$[10.24]^{\star *}$} & {$[2.13]^{*}$} & [1.06] & {$[11.63]^{\star *}$} & {$[1.59]$} & {$[2.97]^{\star *}$} & {$[8.42]^{\star *}$} \\
\hline Observations & 13025 & 13025 & 13025 & 13025 & 13025 & 13025 & 13025 & 13025 & 13025 \\
\hline
\end{tabular}

Absolute value of $\mathrm{z}$ statistics in brackets

* significant at $5 \%$; ** significant at $1 \%$ 
Table 12

Institutional ownership and firm value

\section{System of ownership, firm value (ROA) and leverage}

This table reports estimates of coefficients of the annual time-series cross-sectional firm-level regression of ROA, leverage (BDR); and alternatively, ownership for all financial institutions $(\mathrm{FI})$ in system 1, banks (BANK) in system 2 and institutional investors (INST INV) in system 3. The system of equations is estimated using three-stage least squares. Firm-level control variables include log total assets (LnTA), turnover (TURNOVER), dividend yield (DY), return on equity (ROE), standard deviation of weekly returns(SD), cash holdings (CASH), closely held shares (CLOSE), European industry ROA median (ROA_med), fixed assets proportion (FA_TA), profitability (EBIT_TA), depreciation (DEP_TA) and European leverage median (BDR_med). All regressions include the country-level regressors strength of auditing and reporting (AUDIT), legal regime index (LEGAL), market capitalization of the private bond market to GDP (BOND MARKET), and market capitalization of the stock market to GDP (STOCK MARKET). Refer to Appendix A for variable definitions. The sample period is from 1997 to 2006. t-statistics are in parentheses. Coefficients significant at the $5 \%$ level are in boldface.

\begin{tabular}{|c|c|c|c|c|c|c|c|c|c|}
\hline & \multicolumn{3}{|c|}{-1} & \multicolumn{3}{|c|}{-2} & \multicolumn{3}{|c|}{-3} \\
\hline & ROA & $\mathrm{FI}$ & BDR & ROA & BANK & BDR & ROA & INST INV & BDR \\
\hline $\mathrm{FI}$ & -72.705 & & 0.451 & & & & & & \\
\hline & {$[11.18]^{\star *}$} & & {$[9.40]^{\star *}$} & & & & & & \\
\hline BANK & & & & $\begin{array}{l}-56.187 \\
{[3.70]^{\star *}}\end{array}$ & & $\begin{array}{r}1.788 \\
{[11.52]^{* *}}\end{array}$ & & & \\
\hline INST INV & & & & & & & $\begin{array}{r}-95.192 \\
{[11.66]^{* *}}\end{array}$ & & $\begin{array}{r}0.473 \\
{[7.75]^{\star *}}\end{array}$ \\
\hline ROA & & $\begin{array}{r}-0.009 \\
{[12.52]^{\star *}}\end{array}$ & $\begin{array}{r}0 \\
{[0.45]}\end{array}$ & & $\begin{array}{r}-0.002 \\
{[4.62]^{* *}}\end{array}$ & $\begin{array}{r}-0.001 \\
{[3.59]^{\star *}}\end{array}$ & & $\begin{array}{r}-0.008 \\
{[13.62]^{* *}}\end{array}$ & $\begin{array}{r}0 \\
{[1.50]}\end{array}$ \\
\hline BDR & $\begin{array}{l}-23.958 \\
{[7.59]^{\star *}}\end{array}$ & $\begin{array}{r}-0.206 \\
{[4.76]^{\star *}}\end{array}$ & & $\begin{array}{r}-27.599 \\
{[10.71]^{\star *}}\end{array}$ & $\begin{array}{l}0.008 \\
{[0.44]}\end{array}$ & & $\begin{array}{l}-29.664 \\
{[8.69]^{\star *}}\end{array}$ & $\begin{array}{r}-0.262 \\
{[6.78]^{* *}}\end{array}$ & \\
\hline LnTA & $\begin{array}{r}2.994 \\
{[22.77]^{\star *}}\end{array}$ & $\begin{array}{r}0.037 \\
{[26.26]^{* *}}\end{array}$ & & $\begin{array}{r}2.093 \\
{[20.28]^{* *}}\end{array}$ & $\begin{array}{r}0.01 \\
{[17.67]^{\star *}}\end{array}$ & & $\begin{array}{r}2.981 \\
{[22.90]^{\star *}}\end{array}$ & $\begin{array}{r}0.032 \\
{[25.74]^{* *}}\end{array}$ & \\
\hline TURNOVER & & $\begin{array}{l}0.003 \\
{[1.37]}\end{array}$ & & & $\begin{array}{r}0.004 \\
{[4.13]^{\star *}}\end{array}$ & & & $\begin{array}{l}0.003 \\
{[1.30]}\end{array}$ & \\
\hline DY & & $\begin{array}{r}-0.092 \\
{[1.69]}\end{array}$ & & & $\begin{array}{r}-0.058 \\
{[3.12]^{\star *}}\end{array}$ & & & $\begin{array}{r}-0.11 \\
{[2.11]^{*}}\end{array}$ & \\
\hline ROE & & $\begin{array}{r}-0.017 \\
{[1.64]}\end{array}$ & & & $\begin{array}{c}-0.01 \\
{[1.85]}\end{array}$ & & & $\begin{array}{r}-0.014 \\
{[1.65]}\end{array}$ & \\
\hline SD & & $\begin{array}{r}-0.002 \\
{[2.87]^{\star *}}\end{array}$ & & & $\begin{array}{r}-0.002 \\
{[4.62]^{\star *}}\end{array}$ & & & $\begin{array}{c}-0.001 \\
{[2.07]^{*}}\end{array}$ & \\
\hline CASH & $\begin{array}{l}-15.886 \\
{[8.32]^{\star *}}\end{array}$ & $\begin{array}{r}-0.168 \\
{[6.47]^{\star *}}\end{array}$ & $\begin{array}{r}-0.301 \\
{[19.30]^{* *}}\end{array}$ & $\begin{array}{r}-12.92 \\
{[9.50]^{\star *}}\end{array}$ & $\begin{array}{l}-0.026 \\
{[2.47]^{*}}\end{array}$ & $\begin{array}{r}-0.298 \\
{[15.92]^{\star *}}\end{array}$ & $\begin{array}{l}-17.317 \\
{[8.19]^{* *}}\end{array}$ & $\begin{array}{r}-0.157 \\
{[6.80]^{\star *}}\end{array}$ & $\begin{array}{r}-0.322 \\
{[22.18]^{\star *}}\end{array}$ \\
\hline ROA_med & $\begin{array}{r}0.949 \\
{[8.85]^{\star *}}\end{array}$ & & & $\begin{array}{r}1.52 \\
{[14.59]^{\star *}}\end{array}$ & & & $\begin{array}{r}0.848 \\
{[7.68]^{* *}}\end{array}$ & & \\
\hline
\end{tabular}


Table 12

Institutional ownership and firm value

System of ownership, firm value (ROA) and leverage

\begin{tabular}{|c|c|c|c|c|c|c|c|c|c|}
\hline & \multicolumn{3}{|c|}{-1} & \multicolumn{3}{|c|}{-2} & \multicolumn{3}{|c|}{-3} \\
\hline & ROA & $\mathrm{FI}$ & BDR & ROA & BANK & BDR & ROA & INST INV & BDR \\
\hline CLOSE & & $\begin{array}{r}-0.004 \\
{[0.55]}\end{array}$ & & & $\begin{array}{r}-0.001 \\
{[0.45]}\end{array}$ & & & $\begin{array}{l}0.003 \\
{[0.48]}\end{array}$ & \\
\hline FA_TA & & & $\begin{array}{r}0.125 \\
{[20.15]^{* *}}\end{array}$ & & & $\begin{array}{r}0.105 \\
{[15.09]^{\star *}}\end{array}$ & & & $\begin{array}{r}0.131 \\
{[21.02]^{\star \star}}\end{array}$ \\
\hline DEP_TA & & & $\begin{array}{r}-0.202 \\
{[4.24]^{* *}}\end{array}$ & & & $\begin{array}{c}-0.143 \\
{[2.57]^{*}}\end{array}$ & & & $\begin{array}{r}-0.211 \\
{[4.54]^{\star *}}\end{array}$ \\
\hline BDR_med & & & $\begin{array}{r}0.48 \\
{[22.81]^{\star *}}\end{array}$ & & & $\begin{array}{r}0.412 \\
{[18.37]^{\star *}}\end{array}$ & & & $\begin{array}{r}0.484 \\
{[23.35]^{\star \star}}\end{array}$ \\
\hline AUDIT & $\begin{array}{r}-2.815 \\
{[4.53]^{\star *}}\end{array}$ & $\begin{array}{r}-0.043 \\
{[6.21]^{\star *}}\end{array}$ & $\begin{array}{r}0.064 \\
{[10.81]^{\star *}}\end{array}$ & $\begin{array}{l}0.214 \\
{[0.46]}\end{array}$ & $\begin{array}{r}-0.015 \\
{[5.31]^{\star *}}\end{array}$ & $\begin{array}{r}0.069 \\
{[9.85]^{\star *}}\end{array}$ & $\begin{array}{r}-2.277 \\
{[3.60]^{* *}}\end{array}$ & $\begin{array}{r}-0.025 \\
{[4.05]^{\star *}}\end{array}$ & $\begin{array}{r}0.058 \\
{[10.42]^{\star *}}\end{array}$ \\
\hline LEGAL & $\begin{array}{r}0.256 \\
{[6.63]^{\star *}}\end{array}$ & $\begin{array}{r}0.004 \\
{[12.63]^{\star *}}\end{array}$ & $\begin{array}{r}-0.003 \\
{[10.26]^{\star *}}\end{array}$ & $\begin{array}{r}-0.052 \\
{[2.62]^{\star \star}}\end{array}$ & $\begin{array}{r}0.001 \\
{[4.29]^{\star *}}\end{array}$ & $\begin{array}{r}-0.002 \\
{[7.78]^{* *}}\end{array}$ & $\begin{array}{r}0.305 \\
{[7.21]^{\star *}}\end{array}$ & $\begin{array}{r}0.003 \\
{[12.31]^{\star *}}\end{array}$ & $\begin{array}{r}-0.003 \\
{[9.72]^{\star *}}\end{array}$ \\
\hline BOND MARKET & $\begin{array}{r}9.591 \\
{[6.84]^{* *}}\end{array}$ & $\begin{array}{r}0.136 \\
{[10.00]^{\star *}}\end{array}$ & $\begin{array}{r}-0.142 \\
{[11.22]^{* *}}\end{array}$ & $\begin{array}{r}-0.59 \\
{[0.78]}\end{array}$ & $\begin{array}{l}0.011 \\
{[1.92]}\end{array}$ & $\begin{array}{r}-0.092 \\
{[7.10]^{* *}}\end{array}$ & $\begin{array}{r}11.438 \\
{[7.35]^{\star *}}\end{array}$ & $\begin{array}{r}0.121 \\
{[10.00]^{* *}}\end{array}$ & $\begin{array}{r}-0.14 \\
{[10.89]^{\star *}}\end{array}$ \\
\hline STOCK MARKET & $\begin{array}{r}13.444 \\
{[10.45]^{\star *}}\end{array}$ & $\begin{array}{r}0.178 \\
{[17.52]^{\star *}}\end{array}$ & $\begin{array}{r}-0.073 \\
{[6.56]^{\star *}}\end{array}$ & $\begin{array}{r}1.908 \\
{[3.53]^{\star \star}}\end{array}$ & $\begin{array}{r}0.008 \\
{[1.96]^{*}}\end{array}$ & $\begin{array}{r}-0.007 \\
{[0.76]}\end{array}$ & $\begin{array}{r}16.655 \\
{[10.98]^{\star *}}\end{array}$ & $\begin{array}{r}0.173 \\
{[19.05]^{\star *}}\end{array}$ & $\begin{array}{r}-0.074 \\
{[6.06]^{\star \star}}\end{array}$ \\
\hline year dummies & yes & yes & yes & yes & yes & yes & yes & yes & yes \\
\hline Constant & $\begin{array}{l}-30.923 \\
{[9.37]^{\star *}}\end{array}$ & $\begin{array}{r}-0.314 \\
{[7.27]^{\star *}}\end{array}$ & $\begin{array}{r}-0.201 \\
{[6.05]^{* *}}\end{array}$ & $\begin{array}{r}-32.524 \\
{[12.87]^{\star \star}}\end{array}$ & $\begin{array}{c}-0.041 \\
{[2.33]^{\star}}\end{array}$ & $\begin{array}{r}-0.297 \\
{[7.00]^{* *}}\end{array}$ & $\begin{array}{r}-36.268 \\
{[10.12]^{\star \star}}\end{array}$ & $\begin{array}{r}-0.378 \\
{[9.77]^{\star \star}}\end{array}$ & $\begin{array}{r}-0.131 \\
{[4.46]^{\star *}}\end{array}$ \\
\hline Observations & 12996 & 12996 & 12996 & 12996 & 12996 & 12996 & 12996 & 12996 & 12996 \\
\hline
\end{tabular}

Absolute value of $\mathrm{z}$ statistics in brackets

* significant at $5 \%$; ** significant at $1 \%$ 
Table 13

Institutional ownership and firm value

System of ownership, firm value $(Q)$ and leverage with lagged firm variables

This table reports estimates of coefficients of the annual time-series cross-sectional firm-level regression of ROA, leverage (MDR); and alternatively, ownership for all financial institutions (FI) in system 1, banks (BANK) in system 2 and institutional investors (INST INV) in system 3. The system of equations is estimated using three-stage least squares. All firm-level control variables are lagged one period and include log total assets (LnTA), the lag of turnover (TURNOVER), dividend yield (DY), return on equity (ROE), standard deviation of weekly returns(SD), cash holdings (CASH), closely held shares (CLOSE), European industry ROA median (ROA med), fixed assets proportion (FA TA), profitability (EBIT TA), depreciation (DEP TA) and European leverage median (BDR_med). All regressions include the country-level regressors strength of auditing and reporting (AUDIT), legal regime index (LEGAL), market capitalization of the private bond market to GDP (BOND MARKET), and market capitalization of the stock market to GDP (STOCK MARKET). Refer to Appendix A for variable definitions. The sample period is from 1997 to 2006. t-statistics are in parentheses. Coefficients significant at the $5 \%$ level are in boldface.

\begin{tabular}{|c|c|c|c|c|c|c|c|c|c|}
\hline & \multicolumn{3}{|c|}{-1} & \multicolumn{3}{|c|}{-2} & \multicolumn{3}{|c|}{-3} \\
\hline & $\mathrm{Q}$ & $\mathrm{FI}$ & BDR & $\mathrm{Q}$ & BANK & BDR & $\mathrm{Q}$ & INST INV & BDR \\
\hline$\overline{\mathrm{FI}}$ & $\begin{array}{r}-3.787 \\
{[6.00]^{\star *}}\end{array}$ & & $\begin{array}{r}0.086 \\
{[1.04]}\end{array}$ & & & & & & \\
\hline BANK & & & & $\begin{array}{r}-6.895 \\
{[5.01]^{\star *}}\end{array}$ & & $\begin{array}{r}0.865 \\
{[4.56]^{\star *}}\end{array}$ & & & \\
\hline INST INV & & & & & & & $\begin{array}{r}-4.673 \\
{[6.38]^{\star *}}\end{array}$ & & $\begin{array}{r}-0.118 \\
{[1.16]}\end{array}$ \\
\hline Q & & $\begin{array}{r}-0.086 \\
{[12.48]^{* *}}\end{array}$ & $\begin{array}{r}0.04 \\
{[6.38]^{\star *}}\end{array}$ & & $\begin{array}{r}-0.037 \\
{[12.53]^{\star *}}\end{array}$ & $\begin{array}{r}0.059 \\
{[10.58]^{\star *}}\end{array}$ & & $\begin{array}{r}-0.071 \\
{[11.40]^{* *}}\end{array}$ & $\begin{array}{r}0.019 \\
{[3.00]^{\star *}}\end{array}$ \\
\hline BDR & $\begin{array}{r}-1.596 \\
{[5.67]^{\star *}}\end{array}$ & $\begin{array}{r}-0.156 \\
{[2.92]^{\star *}}\end{array}$ & & $\begin{array}{r}-1.147 \\
{[4.38]^{\star *}}\end{array}$ & $\begin{array}{r}-0.018 \\
{[0.83]}\end{array}$ & & $\begin{array}{r}-1.982 \\
{[6.82]^{\star *}}\end{array}$ & $\begin{array}{r}-0.206 \\
{[4.29]^{\star *}}\end{array}$ & \\
\hline ILnTA & $\begin{array}{r}0.07 \\
{[5.64]^{\star *}}\end{array}$ & $\begin{array}{r}0.017 \\
{[9.90]^{\star *}}\end{array}$ & $\begin{array}{r}0.014 \\
{[10.14]^{\star *}}\end{array}$ & $\begin{array}{r}0.053 \\
{[5.08]^{\star *}}\end{array}$ & $\begin{array}{r}0.007 \\
{[9.29]^{\star *}}\end{array}$ & $\begin{array}{r}0.01 \\
{[6.69]^{\star *}}\end{array}$ & $\begin{array}{r}0.059 \\
{[5.28]^{\star *}}\end{array}$ & $\begin{array}{r}0.012 \\
{[7.56]^{\star *}}\end{array}$ & $\begin{array}{r}0.016 \\
{[14.45]^{\star *}}\end{array}$ \\
\hline ITURNOVER & & $\begin{array}{c}-0.008 \\
{[2.02]^{*}}\end{array}$ & & & $\begin{array}{r}0.004 \\
{[2.19]^{*}}\end{array}$ & & & $\begin{array}{r}-0.011 \\
{[3.07]^{\star *}}\end{array}$ & \\
\hline IDY & & $\begin{array}{r}0.367 \\
{[4.11]^{\star *}}\end{array}$ & & & $\begin{array}{r}0.026 \\
{[0.74]}\end{array}$ & & & $\begin{array}{r}0.373 \\
{[4.52]^{\star *}}\end{array}$ & \\
\hline IROE & & $\begin{array}{r}-0.021 \\
{[3.96]^{* *}}\end{array}$ & & & $\begin{array}{r}-0.006 \\
{[2.77]^{\star *}}\end{array}$ & & & $\begin{array}{r}-0.019 \\
{[3.87]^{\star *}}\end{array}$ & \\
\hline ISD & & $\begin{array}{r}-0.006 \\
{[4.27]^{\star *}}\end{array}$ & & & $\begin{array}{r}-0.003 \\
{[5.19]^{\star *}}\end{array}$ & & & $\begin{array}{r}-0.004 \\
{[3.03]^{\star *}}\end{array}$ & \\
\hline ICASH & $\begin{array}{r}1.546 \\
{[9.55]^{\star *}}\end{array}$ & $\begin{array}{r}0.112 \\
{[3.64]^{\star \star}}\end{array}$ & $\begin{array}{r}-0.407 \\
{[20.80]^{\text {** }}}\end{array}$ & $\begin{array}{r}1.748 \\
{[12.79]^{* *}}\end{array}$ & $\begin{array}{r}0.063 \\
{[5.01]^{* *}}\end{array}$ & $\begin{array}{r}-0.441 \\
{[22.49]^{\star *}}\end{array}$ & $\begin{array}{r}1.441 \\
{[8.50]^{\star *}}\end{array}$ & $\begin{array}{r}0.077 \\
{[2.80]^{\star *}}\end{array}$ & $\begin{array}{r}-0.366 \\
{[18.40]^{\star *}}\end{array}$ \\
\hline IQ_med & $\begin{array}{r}0.62 \\
{[12.36]^{\star *}}\end{array}$ & & & $\begin{array}{r}0.73 \\
{[16.45]^{\star *}}\end{array}$ & & & $\begin{array}{r}0.617 \\
{[12.30]^{\star *}}\end{array}$ & & \\
\hline
\end{tabular}


Table 13

Institutional ownership and firm value

System of ownership, firm value (Q) and leverage with lagged firm variables

\begin{tabular}{|c|c|c|c|c|c|c|c|c|c|}
\hline & \multicolumn{3}{|c|}{-1} & \multicolumn{3}{|c|}{-2} & \multicolumn{3}{|c|}{-3} \\
\hline \multirow{3}{*}{ ICLOSE } & $\mathrm{Q}$ & $\mathrm{FI}$ & BDR & $\mathrm{Q}$ & BANK & BDR & Q & INST INV & BDR \\
\hline & & -0.033 & & & -0.006 & & & -0.024 & \\
\hline & & {$[3.31]^{\star *}$} & & & [1.49] & & & {$[2.78]^{\star *}$} & \\
\hline \multirow{2}{*}{ IFA_TA } & & & 0.129 & & & 0.127 & & & 0.124 \\
\hline & & & {$[17.01]^{\star *}$} & & & {$[16.43]^{\star \star}$} & & & {$[15.89]^{\star *}$} \\
\hline \multirow[t]{2}{*}{ IDEP_TA } & & & -0.277 & & & -0.267 & & & -0.253 \\
\hline & & & {$[5.91]^{\star \star}$} & & & {$[6.00]^{\star *}$} & & & {$[5.09]^{* *}$} \\
\hline \multirow[t]{2}{*}{ IEBIT_TA } & & & -0.211 & & & -0.2 & & & -0.199 \\
\hline & & & {$[11.91]^{\star \star}$} & & & {$[12.03]^{\star *}$} & & & {$[10.62]^{\star *}$} \\
\hline \multirow[t]{2}{*}{ IBDR_med } & & & 0.426 & & & 0.428 & & & 0.409 \\
\hline & & & {$[17.61]^{\star *}$} & & & {$[18.26]^{\star *}$} & & & {$[17.04]^{\star *}$} \\
\hline \multirow{2}{*}{ AUDIT } & -0.229 & -0.054 & 0.035 & -0.191 & -0.021 & 0.05 & -0.167 & -0.032 & 0.026 \\
\hline & {$[3.94]^{\star *}$} & {$[6.26]^{\star *}$} & {$[5.09]^{\star *}$} & {$[3.75]^{\star \star}$} & {$[5.97]^{\star \star}$} & {$[7.26]^{\star *}$} & {$[3.09]^{\star *}$} & {$[4.14]^{\star \star}$} & {$[4.16]^{\star *}$} \\
\hline \multirow[t]{2}{*}{ LEGAL } & 0.016 & 0.004 & -0.002 & 0.005 & 0.001 & -0.002 & 0.017 & 0.004 & -0.001 \\
\hline & {$[4.65]^{\star *}$} & {$[11.42]^{\star *}$} & {$[4.96]^{\star *}$} & {$[2.25]^{*}$} & {$[4.67]^{\star *}$} & {$[8.86]^{\star *}$} & {$[4.86]^{* \star}$} & {$[10.84]^{\star *}$} & {$[2.74]^{\star *}$} \\
\hline \multirow[t]{2}{*}{ BOND MARKET } & 0.589 & 0.141 & -0.089 & 0.186 & 0.017 & -0.092 & 0.615 & 0.122 & -0.059 \\
\hline & {$[4.75]^{\star *}$} & {$[9.24]^{* *}$} & {$[5.82]^{\star \star}$} & {$[2.43]^{*}$} & {$[2.73]^{\star \star}$} & {$[9.11]^{\star \star}$} & {$[4.89]^{\star *}$} & {$[8.86]^{* *}$} & {$[3.62]^{\star *}$} \\
\hline \multirow[t]{2}{*}{ STOCK MARKET } & 0.809 & 0.172 & -0.006 & 0.208 & 0.005 & 0.004 & 0.956 & 0.173 & 0.03 \\
\hline & {$[6.69]^{\star *}$} & {$[13.34]^{\star \star}$} & {$[0.37]$} & {$[3.52]^{\star *}$} & [0.93] & {$[0.54]$} & {$[6.99]^{* *}$} & {$[14.89]^{\star \star}$} & [1.62] \\
\hline \multirow[t]{2}{*}{ Constant } & 1.093 & 0.252 & -0.341 & 1.049 & 0.125 & -0.424 & 0.834 & 0.151 & -0.284 \\
\hline & {$[3.35]^{\star *}$} & {$[4.36]^{* *}$} & {$[8.82]^{\star *}$} & {$[3.58]^{\star *}$} & {$[5.31]^{\star *}$} & {$[10.50]^{\star *}$} & {$[2.57]^{*}$} & {$[2.91]^{\star \star}$} & {$[7.61]^{\star *}$} \\
\hline Observations & 9559 & 9559 & 9559 & 9559 & 9559 & 9559 & 9559 & 9559 & 9559 \\
\hline
\end{tabular}

Absolute value of $z$ statistics in brackets

* significant at $5 \%$; ** significant at $1 \%$ 


\section{Appendix A \\ Definitions of the variables}

Variable

\section{A. Ownership variables} $\mathrm{FI}$

BANK

INST INV

B. Firm-specific variables

Q_med
LnTA
BDR
BDR_med
DY
ROE
ROA

TURNOVER

CLOSE

SD

$\mathrm{CASH}$

EBIT_TA

$\mathrm{MB}$

DEP_TA
Definition

Source

$\%$ of total shareholding where shareholders are financial institutions

$\%$ of total shareholding where shareholders are bank trust Percentage of total shareholding where shareholders are institutional investors
Amadeus

Amadeus

Amadeus

Amadeus + Datastream

Amadeus + Datastream

Amadeus

Amadeus

Amadeus

The firm's industry median debt ratio (using the Fama and French industry classification)

Dividend yield (Datastream item DY)

Return on equity (Datastream item ROE)

Return on assets (WorldScope item 08326)

Annual share volume (Datastream item VO) divided by adjusted shares outstanding (Datastream items NOSH/AF)

Number of shares held by insiders as a proportion of the number of shares outstanding (WorldScope item 08021)

standard deviation of one year of $€$ weekly returns (Datastream items $\mathrm{RI})$

Cash and Cash equivalent / Total assets

Ebit / Total assets

(Current liability loans + long term debt + market value of firm) / Total assets

Depreciation / Total assets
Datastream
Datastream
Worldscope
Worldscope

Worldscope

Datastream

Amadeus

Amadeus

Amadeus + Datastream

Amadeus 


\section{Appendix A \\ Definitions of the variables}

\begin{tabular}{|c|c|c|}
\hline Variable & Definition & Source \\
\hline FA_TA & Fixed tangible assets / Total assets & Amadeus \\
\hline \multicolumn{3}{|c|}{ C. Country-specific variables } \\
\hline AUDIT & $\begin{array}{l}\text { Strenght of auditing and reportings } \\
\text { standards regarding company } \\
\text { financial performance }\end{array}$ & Global competitiveness report \\
\hline LEGAL & $\begin{array}{l}\text { Anti-director rights multiplied by the } \\
\text { rule of law index }\end{array}$ & $\begin{array}{l}\text { La Porta, Lopez-de-Silanes, Shleifer, } \\
\text { and Vishny (1998) }\end{array}$ \\
\hline BOND & $\begin{array}{l}\text { the ratio of private domestic debt } \\
\text { securities issued by financial } \\
\text { institutions and corporations as a } \\
\text { share of GDP }\end{array}$ & World Bank \\
\hline STOCK & the value of listed shares to GDP & World Bank \\
\hline
\end{tabular}


Appendix B

\begin{tabular}{lrrr}
\hline Shareholder Type & Freq. & Percent & Cum. \\
\hline & & & \\
Bank & 20477 & 12.85 & 12.85 \\
Employees/Managers & 742 & 0.47 & 13.31 \\
Financial company & 22361 & 14.03 & 27.34 \\
Foundation & 534 & 0.34 & 27.68 \\
Foundation/Research Institute & 22 & 0.01 & 27.69 \\
Individual(s) or family(ies) & 47703 & 29.93 & 57.62 \\
Industrial company & 18838 & 11.82 & 69.44 \\
Insurance company & 10965 & 6.88 & 76.32 \\
Mutual \& Pension fund/Trust/Nominee & 26815 & 16.82 & 93.14 \\
Unknown & 4346 & 2.73 & 95.87 \\
Other unnamed shareholders & 841 & 0.53 & 96.4 \\
Private Equity firms & 1819 & 1.14 & 97.54 \\
Private individuals / private shareholders & 9 & 0.01 & 97.54 \\
Public & 1973 & 1.24 & 98.78 \\
Self-owned & 827 & 0.52 & 99.3 \\
State, Public authority & 591 & 0.37 & 99.67 \\
Unnamed private shareholders & 526 & 0.33 & 100 \\
& & & \\
\hline Total & 159,389 & 100 & \\
\hline
\end{tabular}

\begin{tabular}{lrrr}
\hline year & FI & BANK & INST INV \\
\hline & & & \\
1997 & 41.22 & 9.54 & 32.45 \\
1998 & 32.27 & 7.47 & 25.32 \\
2009 & 29.24 & 6.75 & 22.9 \\
2001 & 26.42 & 5.94 & 20.81 \\
2002 & 18.02 & 3.68 & 14.35 \\
2003 & 17.69 & 3.2 & 14.52 \\
2004 & 18.31 & 3.23 & 15.12 \\
2005 & 18.71 & 3.3 & 15.45 \\
2006 & 23.67 & 3.97 & 19.77 \\
& 31.43 & 6.7 & 25.18 \\
\hline Total & & & \\
\hline
\end{tabular}

